Fernando Retamal

Profesor de la Facultad de Teología

Pontificia Universidad Católica de Chile

\title{
El ejercicio del poder en la Iglesia
}

De cara a un tema tan vasto, en el marco de un Seminario de colegas, he pensado en la utilidad de seleccionar algunos elementos o colindantes con otras disciplinas teológicas, Eclesiología, Teología oriental, Historia de la Iglesia, Derecho Público Eclesiástico y otras, que hagan posible un diálogo enriquecedor para todos. Esto ha de constituir la Primera Parte de nuestra exposición.

Tales subtemas los enunciamos así:

1. La potestad imperial de Constantino en la Iglesia del primer milenio;

2. La potestad papal en la Cristiandad;

3. Los desafíos de la época moderna y contemporánea.

Como trasfondo de estos subtemas, aparecerán los grandes rasgos de la evolución del Derecho de la Iglesia, que permitan situarlos en su adecuado contexto.

La Segunda Parte constituye una consideración de conjunto sobre la nueva visión eclesial que reclama el Derecho de la Iglesia por parte de las demás asignaturas teológicas, en el contexto del tema que ahora nos interesa.

\section{PRIMERA PARTE}

\section{INTRODUCCIÓN}

\section{El período preconstantiniano}

Las primeras comunidades cristianas aparecen en los escritos neotestamentarios constituidas a medida humana, donde todos se conocen como "hermanos"; con excepción de las comunidades joánicas, las demás presentan un núcleo dirigente, que se estructura sobre todo en las funciones del obispo y del diácono, siendo este último encargado especialmente del ejercicio de obras de asistencia y caridad. El conocimiento de las directivas litúrgicas y disciplinares nos ha llegado a través de la Didaché o Doctrina de los Doce Apóstoles, compuesta seguramente en Siria hacia los comienzos del siglo II. 
La complejidad creciente de las relaciones eclesiales y el aumento de las comunidades lleva al episcopado a consolidarse mientras declina el papel de los diáconos, que era central para la organización de la autodefensa de los grupos durante las persecuciones, y a medida que avanza el proceso de legitimación social de la nueva fe.

Al mismo tiempo, a raíz de una cierta ósmosis con las religiones paganas, se observa una "sacerdotalización "del ministerio, de modo que aumenta el prestigio del colegio de los presbíteros, encargados de presidir la eucaristía en lugares donde el obispo se halla distante.

El reconocimiento legal del cristianismo, a comienzos del s.IV, hace sentir la necesidad de una coordinación interepiscopal e impulsa una primera formalización de producción jurídica, hecha necesaria por una dialéctica más compleja que el simple testimonio antipagano. Estas nuevas exigencias (estamos en el auge del arrianismo), abren el camino a una incipiente legislación sinodal y a la progresiva articulación de una jerarquía entre las diversas sedes episcopales.

En un primer tiempo se da una relación "parental" entre una "iglesia-madre" y una "iglesia-filial" derivada de ella, lo que implica la prioridad del metropolita y posteriormente de los patriarcas, que presiden las "sedes apostólicas" o Pentarchia (Jerusalem, Antioquía, Roma, Alejandría, Constantinopla).

Dado que Constantinopla carece de fundamentos bíblicos para consolidar su creciente prestigio, su patriarca es apoyado firmemente por el emperador para enfrentar la condición eclesial del obispo de Roma (siempre más insistente a partir del siglo V) y ser considerado como "patriarca ecuménico".

El papel de Roma como primera sede tiende a aparecer como subversivo, en un contexto cultural propenso a reconocer al basileus bizantino un poder sagrado, a menudo arbitrario, sobre la actividad del gobierno eclesiástico y sobre los dignatarios legítimamente investidos, llegando a deponer al papa Silverio (a. 537) у а condenar a muerte a Martín (a. 655).

Esto nos conduce al primer subtema de nuestra reflexión.

\section{LA POTESTAD IMPERIAL DE CONSTANTINO EN LA IGLESIA DEL PRIMER MILENIO}

Entre los factores que se anotan como favorables para la inserción de la Iglesia en los planteamientos políticos de esa sociedad contemporánea, aparece la antigua deificación de los Emperadores romanos y su permanencia, bajo nuevos matices, a partir de Constantino.

La divinización de los emperadores que había tenido lugar hasta entonces dejaba al descubierto una idea no demasiado elevada de Dios; se había debilitado la distinción entre lo divino y humano, que tan claramente aparecía en el primer paganismo. En cambio ahora, cuando con el cristianismo Dios sea concebido como más radicalmente trascendente, los atributos reconocidos al emperador lo van a elevar por encima de los hombres comunes. La persona del emperador y su poder no serán menos sagrados y reflejarán la majestad terrible del Dios del Sinaí. 
El núcleo de la "cuestión constantiniana" parece constituirlo la "episcopalidad" del emperador (1). La única interpretación posible de ella es la de que en la persona del emperador se identificaban la autoridad imperial y la eclesiástica, resucitando así el esquema monista de las naciones precristianas, incluida la misma Roma imperial. La expresión "episcopus" (gr.) es utilizada en su significado como "supraintendente de la Iglesia”, es decir del pueblo cristiano, con las atribuciones y autoridad que eran peculiares a la autoridad episcopal, solo que el emperador las ostentaba y ejercía en el ámbito universal del imperio. A diferencia de los obispos elegidos por la plebe cristiana y consagrados mediante la "jeirotonía" de, por lo menos, tres obispos (cf. cánones de Nicea y de Arlés), el emperador es constituido "episcopus" directamente por Dios, como una concreción de la sentencia paulina "Non est potestas nisi a Deo" (Rom 13, 1), frecuentemente recordada a partir del s. II. La autoridad imperial va a centralizar en sí la tarea de guiar cristianamente al Imperio; su acción se extenderá a los paganos y a los herejes, pero su punto de partida deriva del concepto político-religioso de la "misión" y de la autoridad divina del emperador y de su campo de competencia entre los súbditos cristianos del imperio. Mientras la actuación imperial permanezca como un impulso para la cristianización del imperio, de sus leyes e instituciones, la Iglesia no tendrá inconveniente en apoyarla incondicionalmente. En cambio, si el "imperator-episcopus" amenaza la autonomía de la Iglesia o se interpone en la solución de los problemas que tocan al dogma, las relaciones se harán críticas. De este modo, cuando más tarde Constancio busque unificar religiosamente al imperio ya políticamente unido e imponga una línea oriental y arriana (hacia el 355), van a diferenciarse con mayor nitidez los ámbitos imperial y eclesiástico. Incluso, en esos momentos críticos, la doctrina eclesiástica va a mirar las mutuas relaciones como distinción/separación de competencias, pero no como una superioridad de lo religioso sobre lo estatal. La teología política del emperador podría sintetizarse presentando a la "ecclesia" como un círculo menor, contenido en otro mayor, la "respublica", ambos concéntricos, ("ecclesia in republica..."): en el centro, el emperador, "imago Dei" y el obispo, "imago Christi".

Esta "coincidencia" de funciones "episcopales" de la autoridad imperial con las de la jerarquía de la Iglesia dejaba abierto el camino a futuros conflictos. Apenas deje de ser ortodoxo, el santísimo y piadosísimo emperador se transformará en un tirano, perseguidor, precursor del Anticristo.

Las voces que se alzan en nombre de la Iglesia alcanzan su máxima expresión en Atanasio (=en su episcopado va a acumular diecisiete años de destierro bajo cuatro emperadores), Liberio obispo de Roma y Osio de Córdoba. Con anterioridad

(1) Entre los textos atingentes, puede verse la epístola Constantiniana a la Iglesia de los Alejandrinos acerca del Concilio Niceno I: “(...)Unum igitur omnes Deum et nomine adoramus et esse credimus. Porro ut id fieret, Deo suggerente, convocavi in urbem Nicaeam quamplurimos episcopos, quibuscum ego unus ex vestro numero, qui me vestrum conservum esse magnopere gaudeo, veritatis examen suscepi.(...)" PG 67, 83 - 86. Un texto de Eusebio es aún más elocuente": Quocirca non absurde, cum episcopos aliquando convivio exciperet, se quoque episcopum esse dixit, his fere verbis usus nobis praesentibus": Vos quidem-inquit - in iis quae intra Ecclesiam sunt, episcopi estis.Ego vero in is quae extra geruntur episcopus a Deo sum constitutus". Itaque concilia capiens dictis congruentia, omnes imperio suo subiectos episcopali sollicitudine gubernabat, et quibuscumque modis poterat, ut veram pietatem consectarentur incitabat." PG 20, 1171.Cf. también la condena de los escritos de Arrio, en PG 67, 87 - 90, etc. 
hubo otras disensiones al interior de la Iglesia: recordemos a Tertuliano, a Orígenes rechazado por el obispo de Alejandría; a Hipólito, que se alza contra los obispos de Roma, Ceferino (197-217) y Calixto (217 - 222), reprochándoles su mundanidad y laxismo. En estos y otros conflictos, simplificando al máximo las diversas posturas que se enfrentan, Danielou ve una raíz común: se trata de intelectuales, seducidos por una Iglesia ideal, frente a pastores conscientes de la Iglesia real. Aquí él traslada ya el problema de las relaciones con el Imperio.

Por su parte, Víctor de Reina sitúa, a partir de Constantino, una época que él llama el "dualismo constantiniano: "emperadores y obispos como autoridades autónomas, que contribuyen, cada una a su modo, a la expansión y consolidación del Cristianismo. Dicha situación perdura hasta que comienza el problema histórico entre Sacerdocio y Reino, en tiempos de Gregorio VII. En este forcejeo dialéctico habrá un intento teórico de absorción del poder político en el poder sacerdotal y se mantendrá incluso cuando el estado de cosas originado en Constantino, vencido momentáneamente el cesaropapismo en Occidente, dé paso a la legislación confesional por excelencia: la teodosiana" (2). La función del emperador Constantino como episcopus ad extra, que pasará a sus sucesores, lleva a admitir pacíficamente en el ambiente de la Pentarchia, la opinión de que es facultad imperial el ratificar los nombramientos patriarcales (sin excluir la del obispo de Roma, patriarca de Occidente), la convocación de concilios ecuménicos y la confirmación de sus decisiones. De este modo, entre el concilio de Nicea (325) y el II Trullano o Quinisexto (692) se va formando un incipiente derecho canónico "coloris romani", que abarca "cánones" conciliares, escritos neotestamentarios o patrísticos y "nomocánones", es decir, leyes imperiales sobre materias eclesiásticas.

La así llamada "era constantiniana" viene a significar solamente un modo determinado de concebir las relaciones de la Iglesia con el poder temporal y su correspondiente estatuto jurídico. En tal caso, es posible individuar algunos elementos que, nacidos allí, se mantendrán en lo substancial, sin perjuicio de su evolución histórica en el planteamiento de estas relaciones.

a) El primer elemento es la utilización del Cristianismo como punto de apoyo para consolidar una determinada forma política.

Sin juzgar intenciones, es evidente que a partir de entonces el Cristianismo revitalizó el Imperio Romano, y se impregnó de elementos no siempre congruentes con su propia esencia. No es del caso detenernos en los valores que encierra el "derecho romano-cristiano" compilado por orden del emperador Justiniano (s.VI), en lo que significó de mitigación de penas, ciertos derechos reconocidos a la persona humana, etc.

Con todo, no falta quien piense que tal utilización es inevitable, mientras el cristianismo sea visto como una "religión", en su acepción más usual e inauténtica de esta palabra: si el Cristianismo es manipulado como mera ideología -incluso en el mundo democrático de hoy- será inevitable que sobre él se apoyen unas u otras soluciones políticas.

(2) Const. "Cunctos populos" (D.III Kal.Mart- 27-febr.-380- Thessalonica Gratiano V et Theodosio AA. conss.). Es bien sabido que con esta Constitución del emperador Teodosio, que eleva el Cristianismo al rango de religión oficial del Imperio Romano, comienza el Codex de Justiniano (s.VI), Cf. edit. Paulus Krueger, 1967,5. 
Danielou, en su intento por nivelar exageraciones polémicas, sostuvo que el problema religioso es un problema de masas, no de élites, y que a este nivel, "religión" y "civilización "se encuentran estrechamente unidas, de dos modos: a) no hay verdadera civilización que no sea religiosa; y b) una religión de masas, del pueblo, necesariamente ha de estar sostenida por una civilización. Sigue diciendo que la conversión de Constantino hizo accesible el evangelio a los pobres, es decir, a aquellos que respiran de acuerdo a los cuadros sociales y culturales en que están insertos y no forman parte de ninguna minoría (3).

Según Víctor de Reina, el problema está mal planteado. Si toda civilización ha de ser religiosa, eso puede verificarse de muchas maneras; fundamentalmente es suficiente que tal civilización esté abierta a las verdades trascendentales y salvíficas. Pero no es eso lo que caracterizó a la tradición inaugurada por Constantino, donde la progresiva civilización que se fue formando, se llamó "cristiana", por antonomasia, alcanzando una exclusividad que pone al descubierto lo incorrecto del argumento aducido (4).

Por otro lado, el cristianismo como "religión de masas" puede llevarnos a un grave equívoco. La salvación cristiana tiene un carácter suprarreligioso: no es simplemente una "religión" más, a la manera de cualquier otra, sino la revelación de que Dios ha entrado realmente en comunión con cada hombre. La fe no anula la religiosidad que se expresa en un culto, que se nutre por lo tanto de elementos válidamente fundados en la naturaleza humana. Pero entonces, esa civilización que es "necesaria" para que el cristianismo se convierta en "religión de masas", se convierte en la forma por antonomasia, no ya de la religión cúltica de un pueblo, sino de la trayectoria de la salvación del hombre; pasa a ser su único molde histórico, y esto es lo que inconscientemente sucedió con la era constantiniana. Además, si bien es cierto que la participación en la vida cristiana admite grados, no puede tenerse como actitud válidamente consecuente la que no implica una libre adhesión personal. Y esta gradualidad puede suceder y, de hecho se da, en una religión cuya connotación capital sea "multitudinaria", sin querer prejuzgar ni desmerecer de tantas expresiones de masiva piedad popular.

En síntesis, donde el Cristianismo constituya la ideología básica, será inevitable la supervivencia de la era constantiniana y lo que ella representa, aunque sea bajo matices variables.

b) La era constantiniana, en segundo lugar, aparece caracterizada por el papel asignado en ella al poder político en la expansión del mensaje evangélico, como es el difícil tema de la "cristianización de las estructuras temporales". Dejemos de lado que algunos piensen que es inevitable que todo poder político actúe así con respecto a la ideología que le sirve de sustento o que haya otros que crean ver en este proceso un factor "providencial" para la difusión del Cristianismo a través de la historia.

En cambio la evangelización de los pobres, no necesitó la conversión de Constantino, pues ya había comenzado a producirse en los tiempos apostólicos. Más bien

(3) Danielou J., L'oraison probléme politique, Paris 1965, passim.

(4) De Reina V., La llamada "era constantiniana", en Atti del Congresso Internazionale di Diritto Canonico, Roma 1970, Tomo II/1,572 ss. 
es dado pensar que el mensaje cristiano alcanzó un cierto oscurecimiento de su sentido escatológico, precisamente con tal "conversión" constantiniana.

Es un hecho que la Iglesia a través de la historia buscó el apoyo del poder político para la tarea misional, pagando así tributo a la mentalidad de la época. Dado que el poder político tiene en su mano todo el aparato coactivo para obtener el cumplimiento de las leyes, es claro que ello no es el mejor medio para la libre evangelización. Será suficiente que el poder temporal esté en situación de crear las condiciones naturales que hagan posible tal evangelización. Con todo, este fue un problema que afectó no solamente a la Iglesia católica, sino también a las reformadas del s.XVI (Inglaterra, Suecia, etc.) y aún subsiste en algunas Iglesias ortodoxas, como es el caso de Rusia y Grecia.

Otro tanto hay que decir con respecto a la cristianización de las estructuras temporales, si se entiende por esto el que no haya impedimento para que quienes forman parte de ellas puedan vivir conforme a su fe en Cristo, y que la estructura misma de algún modo manifieste matices cristianos, a fin de que el cristianismo no aparezca solo como reducido a la interioridad humana. Para lo primero (=vivir conforme a su fe en Cristo), no se necesita para nada el poder político: este, a lo sumo, ha de hacer posible la libertad religiosa en lo civil, que permita tales actos religiosos. En cuanto a lo segundo, dado que toda estructura es un elemento de una civilización, atribuir al poder político una tarea de "cristianización" de tales estructuras, es asignarle un papel absolutamente ajeno.

El Vaticano II nos ha hecho ver que la obra redentora de Cristo abarca también la "instauración de todo el orden temporal". Ahora bien, dado que el orden temporal goza de autonomía propia que ha estar abierta a los valores trascendentes, tal cristianización ha de llevarse a cabo mediante el apostolado y el testimonio de los mismos cristianos, de modo que, observando sus propias leyes (cf.G.Sp 36; Ap. Actuosit.3, etc.) el orden temporal resulte conforme a los principios cristianos (y esto tiene gran actualidad en nuestros días).

c) Una tercera característica de la "era constantiniana" es la confesionalidad del Estado, a la que da término el Vaticano II, al definir la situación de la Iglesia Católica con respecto a la comunidad política (G.Sp 76); más aún, el $\mathrm{N}^{\circ} 6$ de la Declaración "Dignitatis Humanae", acerca de circunstancias que pueden llevar a un reconocimiento especial de alguna confesión religiosa (5), no cabe en el antiguo molde confesional, conforme a la doctrina anteriormente sustentada.

Dentro del marco de la formación/evolución del derecho de la Iglesia, acorde con lo visto recién, cabe anotar que los 102 cánones del concilio Quinisexto (que nunca fue aceptado por Roma como legítimo ni ecuménico) son el inicio del derecho canónico bizantino, elaborado con alto grado de finura cultural y es expresión de los estrechos lazos que lo unen al poder imperial. De tal derecho muy pronto empiezan a difundirse colecciones en Oriente, antes que en Occidente, debido a su temprano

(5) “(... Si, en atención a peculiares circunstancias de los pueblos, se otorga a una comunidad religiosa determinada un especial reconocimiento civil en el ordenamiento jurídico de la sociedad, es necesario que al mismo tiempo se reconozca a todos los ciudadanos y comunidades religiosas el derecho a la libertad en materia religiosa". (Dign. Humanae, 6 \& 3). 
desarrollo cultural y a que el conocimiento del griego al principio hace innecesaria la tarea que deberá asumirse en occidente: la traducción o reelaboración latinas de las compilaciones orientales. Aquí hay que situar el Syntagma canonum y la Collectio quinquaginta titulorum (6).

En Occidente, en cambio, van a tener especial relevancia: la colección de Dionisio el Exiguo, elaborada en Roma, en tiempos del papa Gelasio (fines del s.V), que se difundirá en las Galias, y la Hispana-Isidoriana, en Hispania; ambas colecciones se caracterizan por su tendencia universalista, en virtud de lo cual se da especial importancia a las decretales de los papas, que son respuestas a consultas planteadas desde las iglesias de Occidente. En Oriente se incuba una pretensión de autonomía frente a Roma y un sentimiento, apenas disimulado, de superioridad eclesial. A mitad del siglo IX, el patriarca Focio impulsa la formación de un cuerpo único de derecho, a partir del Syntagma e incluyendo fuentes que Roma estima inaceptables (7). Frente a esta estrategia de legitimar el particularismo de Bizancio, Roma apoya una controversia acerca de la legitimidad del patriarca Focio, lo que lleva primero a su deposición y luego a la reasunción de su cargo, con la secuela de recíprocos resentimientos, que es fácil imaginar.

Por este tiempo, en el amplio territorio del patriarcado de Occidente se empieza a desconfiar de las compilaciones griegas y se echa manos de las reediciones, renovadas, de la Colección Dionisiana y de los libros penitenciales de las islas Británicas. Con el contrato de protección feudal acordado entre Pepino el Breve y el papa Esteban II, se abre paso una reacción todavía mayor de sentimientos antibizantinos; por entonces tiene lugar la primera falsificación: el Constitutum Constantini (754).

En este proceso de recíprocas condenas que prepara ya de cerca al Cisma de Oriente (1054), las falsificaciones carolingias proporcionan base documental a las aspiraciones jurisdiccionales romanas. Algunas decretales apócrifas -especialmente las Pseudoisidorianas- serán aceptadas como auténticas por los estudiosos y formarán parte de compilaciones oficiales de los tiempos siguientes.

- En medio de notables contradicciones, el Imperio romano ha sido el primer terreno de inculturación del cristianismo y una vez perpetrado el Cisma (1054), el Imperio acompañará al Oriente ortodoxo hasta mediados del siglo XV.

En este "humus" de la civilización romana, el cristianismo ha robustecido tanto su proyección universal como la conciencia del deber de solidaridad que tal proyección lleva implicada. La primera cristiandad vivió así la solidaridad con la institución política dominante, como un dato natural de su existencia, a partir del siglo IV-V (el período de los Concilios ecuménicos de Nicea,

(6) Para una primera aproximación a estas y a las siguientes Colecciones canónicas aquí citadas, pueden ser útiles los clásicos A.Van Hove, Prolegomena, 1945, 671 pp.; A.Stickler, Historia Iuris Canonici Latini, I. Historia Fontium, Torino, 1950,468 pp., P.Andrieu-Guitrancourt, Introduction... du Droit Canonique... 1963, 1403 pp., etc.

(7) Van incluidos ahora los cánones del II concilio Niceno (a.787) y de otros sínodos bizantinos; además una selección de escritos de doce Padres griegos y una exposición sistemática de los nomocánones. 
Constantinopla, Efeso y Calcedonia). La convocación de los concilios, vista como legítima manifestación del deber cristiano del "basileus", va desarrollando (algún autor ha hablado de una "providencial función mayéutica") la dimensión de comunión, como núcleo básico de la tradición ecuménica, además de la garantía jurídica externa.

El vigor de esta relación Imperio romano-Cristiandad fue vivido diversamente en el área occidental, donde a partir del s.VII las primeras iglesias con amplia base territorial se disolvían en la general disgregación política y militar y las que surgían eran romano-bárbaras. Los nuevos vínculos del episcopado latino y de su patriarca de Roma (el Papa) con los nuevos pueblos no romanos y sus monarcas, no podían menos de alimentar la sospecha bizantina de una falta de lealtad de la Sede romana a los principios de solidaridad irrenunciables para el sistema federativo de la antigua cristiandad ecuménica.

En este contexto, el cisma de Oriente representa raíces populares muy profundas en ambas áreas del antiguo Imperio de los Romanos. Tales raíces se conectan de preferencia a esa variante en la civilización occidental tardo-antigua, determinada por el asomarse de las poblaciones germánicas a las márgenes del Mediterráneo: este fenómeno, casi del todo ajeno al Oriente cristiano, iba ayudando al Occidente a descubrir -por primera vez después del edicto de Constantino (313) - que la historia cristiana no necesariamente lleva una secuencia lineal, y menos aún en su forma eclesiástica.

\section{LA POTESTAD PAPAL EN LA CRISTIANDAD MEDIEVAL}

A partir del pontificado del monje Hildebrando (papa Gregorio VII) comienza a concretarse un profundo reordenamiento de la constitución eclesiástica. Según la mayoría de los tratadistas, el Dictatus Papae (ca.1075) viene a ser como el enunciado sintético del programa teocrático del mencionado Papa. No es del caso traer aquí a colación las numerosas colecciones canónicas que preceden inmediatamente la reforma gregoriana o son expresión de ella ni tampoco las características de cada una. A través de ellas maduran los presupuestos culturales de la gran construcción sistemática a que va llegando el derecho canónico occidental, tres siglos después del de Oriente. Ahora se busca la reforma de la Iglesia mediante el reconocimiento de la potestad suprema y universal del Papa.

El proceso y la sucesiva transformación, ha sido rotulado como "el Agustinismo político", en cuanto no refleja tanto el pensamiento mismo de S. Agustín cuanto la interpretación que recibe en este nuevo contexto. En esencia, consiste en la progresiva absorción de lo natural en lo sobrenatural, sobre la base de ciertos textos agustinianos.

Cuando Agustín considera peyorativamente lo secular, no busca su destrucción, sino el considerarlo bajo una nueva luz: el Estado no será la forma final de la comunidad humana, sino el instrumento regulador de las relaciones del "homo exterior": cumple sus funciones con métodos intimidatorios para los malos y permisivos para los buenos; las instituciones seculares tienen cierta razón y utilidad (cf. Epist.153, 16); el Estado puede reconstruir, pero no regenerar. No puede haber 
transacción entre Cristo y César: este debe someterse a Aquel y no pretender ser independiente ideológicamente a los principios cristianos; de lo contrario, debe (8) prepararse para las consecuencias del pecado y del error en su conflicto con la justicia y la verdad.

Agustín ve la historia distinguiendo dos sociedades en la ciudad celestial y la terrena: "Las dos usan por igual de los bienes temporales o son afligidas por iguales males; pero su fe, su esperanza y su caridad son diferentes hasta que sean separadas en el juicio final y llegue cada una a su fin, que no tendrá fin".

\section{Inicios de la ciencia del derecho canónico}

Al monje Graciano, docente en la Universidad de Bolonia, corresponde el mérito de haber iniciado la ciencia del Derecho canónico como distinta de la teología, en su magna obra Concordia discordantium canonum (ca.1139-1151) (9): no se trata de una recopilación de fuentes, sino de un comentario científico y de un texto de enseñanza universitaria, lo que confiere al Decretum magistri Gratiani, como empieza a ser conocida la "Concordia", un inmenso prestigio y autoridad. Tanto los glosadores del Derecho Romano como los del Canónico están impulsados por un esquema unitario, en búsqueda de una integración cultural entre Iglesia y Regnum que, a través de la institucionalidad cristiana es ya, de hecho, base y fuente vital de una sociedad política: la Cristiandad, cuyo derecho público se inspira concretamente en modelos bastante diversos de los de las fuentes del antiguo derecho romano. Sobre este trasfondo los presupuestos constructivos de los dos sistemas (= romano y canónico) que se unifican en el derecho común, proponen convergencias que confirman el principio del "sincronismo de las instituciones", que preside su desarrollo.

Es interesante anotar que en este período resurge el papel de la costumbre, como fuente jurídica, cuando las mediaciones de la colegialidad episcopal y de la práctica sinodal anteriores a Gregorio VII habían sido sacrificadas al doble esquema monárquico de la jurisdicción pontificia y la del obispo diocesano. La costumbre alude al papel de los abades o de los príncipes, o bien aprovecha el favor de las corporaciones o de las órdenes mendicantes o de la magistratura ciudadana; prácticas más acordes con la piedad popular se insinúan entre las redes del derecho común y, cuando resultan costumbres contra legem, se esfuerzan por quedar ratificadas como "privilegios".

Hay casos, por entonces, de sectores eclesiásticos consolidados que se oponen a recibir una ley pontificia -a pesar del empeño de los obispos interesados-, que el pueblo advierte serle extraña e incongruente; la doctrina califica tal actitud de rechazo como una "consuetudo ecclesiae romanae", y como tal no obligatoria en otros lugares para quienes viven conforme a legítimos usos preexistentes.

En este punto es decisivo un pasaje del Decretum Gratiani, según el cual la ley, si bien existe desde el momento de su promulgación, se consolida mediante el uso de la comunidad que la recibe (=principio de recepción) (10).

(8) Civitas Dei, lib.XVIII, c.54, in fine (trad. B.A.C.).

(9) Corpus Iuris Canonici, (...) instruxit Aemilius Friedberg, Pars prior, Graz 1959.

(10) "Leges instituuntur cum promulgantur, firmantur cum moribus utentium approbantur. Sicut enim moribus utentium in contrarium nonnullae leges hodie abrogatae sunt, ita moribus utentium ipsae 
Por otro lado, por influencia de las ideas de la realeza feudal, se instaura un conjunto de limitaciones al poder papal, en beneficio del colegio cardenalicio o del concilio general. En esta época se reafirma la costumbre según la cual la competencia papal se ejerce según: -la persona; -el tiempo; -y la causa, y no simplemente "per meram voluntatem", ni tampoco en forma general. La potestad papal, se dice, ha de manifestarse exclusivamente como una confirmación apostólica de una disposición anterior que se hallara incierta; -o bien, como una dispensa, "misericordiae causa"; o bien, finalmente, como otorgamiento de un privilegio, que responde a un justo motivo.

De esta costumbre constitucional se seguirá la incapacidad papal para emanar por sí solo (=sin el concurso de un concilio general) normas innovadoras para toda la Iglesia: así como el principio de derecho público feudal otorga a la Dieta la representación del pueblo, se aplica ahora el antiguo principio canónico "Quod omnes uti singulos tangit, ab omnibus probari debet" (X, I, 6 de electione et electi potestate, cc.1, 22,42, 48, 50, 55, 57, con especial aplicación a los actos eleccionarios)

La sensibilidad acerca de estos principios de monarquía limitada empieza a debilitarse al cabo del largo pontificado de Inocencio III (1198 - 1216); el Papa empieza a edictar decretales "de consilio fratrum nostrorum" (= es decir, por consejo del Consistorio de cardenales, competente para tratar las "causas mayores"), en materias que antes eran adoptadas" sacro approbante concilio". Será el derecho de las decretales el que terminará por echar en desuso la obligación de un concurso sinodal para aquellas normas pontificias que tengan aplicación universal.

\section{El derecho de las decretales}

La autoridad del Decretum Gratiani radicaba en la inmediata y general aceptación que tuvo en todas partes; debido a él se había recogido y transmitido en forma didáctica y moderna una antigua tradición ya consolidada.

El pontífice Gregorio IX (1227-1241) adopta una decisión inusitada: encarga al canonista catalán Raimundo de Penyafort la recopilación de una nueva colección, que dará lugar al llamado "Liber Extra". Con el pretexto de completar el Decretum Gratiani se evade el principio de la selección de las Fuentes aprobadas por la tradición, sustituyéndolo por la "aprobación específica del Romano Pontífice". El único punto de conexión con el anterior consensus populi Dei (=con respecto a las decretales aprobadas en un Consistorio) va a ser el envío de la Colección con la bula aprobatoria, a la universidad de Bolonia (11).

Aquí hay que situar enseguida las restantes colecciones que integrarán el Corpus Iuris Canonici:- el Liber Sextus (Bonifacio VIII, 1298) y las Clementinas (Juan XXII, 1317). Dicho Corpus llegará a situarse a igual nivel que el Corpus Iuris Civilis, es decir, el Derecho Romano en la recopilación del emperador Justiniano (s.VI). Ambos serán en adelante enseñados como el utrumque ius, en las universida-

leges confirmantur. Unde illud Thelesphori Papae (quo decrevit ut clerici generaliter a quinquagesima a carnibus et deliciis ieiunent) quia moribus utentium approbatum non est, aliter agentes transgressionis reos non arguit". (D. IV, dictum ad c.3).

(11) Bula Rex pacificus (5-sept.-1234), en Friedberg, II, 2-3. 
des donde surgen notables comentaristas (los "Decretalistas") junto a los Glosadores del derecho romano.

El derecho de las Decretales exhibe gran finura técnica y notable influencia cultural y política, pero al mismo tiempo implica un empobrecimiento en cuanto a los dinamismos eclesiales tradicionales; queda ahora consolidado el clericalismo de la pirámide impulsada por Gregorio VII, en cuyo vértice está el Pontífice "legibus solutus". De este período son la deposición del emperador Federico II (Barbarroja), la lucha contra el ámbito político "autónomo" y, como contrapartida, la "cautividad de Avignon", por la cual el Papa, lejos de Roma, queda desarraigado de su munus episcopale.

La lucha entre el Sacerdocio y el Imperio en tiempos del papa Hildebrando (Gregorio VII), terminó con la confusión de poderes y el monismo religioso de la teocracia anterior. Una nueva organización sociológica de relaciones entre Iglesia y mundo da lugar a la Cristiandad, que resulta, a su vez de la distinción /unificación de ambos en el servicio del fin religioso.

La trascendencia del fin religioso, pone por encima de todo a la Iglesia, que es la que lo realiza; todo lo demás queda en categoría de servidor. En la cima de todo, está el Papa, jefe de la Cristiandad, porque es cabeza de la Iglesia y guía a la prosecución del fin último, sobrenatural.

En el orden de los medios: -en lo político: el Sacro Imperio romano-germánico; -en lo cultural: la Universidad de París (=la ciencia humana al servicio de la $\mathrm{Fe}$ ).

Este fue el esquema histórico ideal que guió a la segunda mitad de la Edad Media, aun cuando no todos lo vieron así. Hubo quienes estimaron que continuaba el monismo religioso de antes y hablaron de un poder directo del Papa en lo espiritual y temporal; este último, lo ejercía mediante la autoridad civil. Después, en una especie de justificación retrospectiva, se habló de un poder indirecto -"ratione peccati"- sobre los asuntos temporales: se buscaba así salvaguardar la distinción entre lo espiritual/ temporal y su unión estrecha y jerarquizada.

La controversia entre el Papado y el Imperio llegó a su culminación en el pontificado del papa Bonifacio VIII (1294-1303).

La bula Unam sanctam (18-nov.-1302), emitida con ocasión de la controversia con el rey Felipe el Hermoso, de Francia, es una completa exposición de la doctrina papal en esta época acerca de la relación entre las dos potestades (12).

Sobre la base del texto evangélico de las dos espadas, se apoya en argumentos y metáforas de la doctrina común de S. Bernardo, Hugo de S. Víctor, Alejandro de Hales, Egidio Romano y Tomás de Aquino. Hay que tener presente que tan solo la última cláusula de la Bula adquiere la connotación de una definición dogmática ("Porro subesse Romano Pontifici omni humanae creaturae declaramus, dicimus, diffinimus omnino esse de necessitate salutis”), no así el resto de la Bula, que aparece más bien como una introducción que prepara el camino a la definición dogmática. Esta se conecta íntimamente con la sentencia que aparece al comienzo y viene a ser su corolario: "Extra ecclesiam salutem non esse nec peccatorum remissionem”. Una vez admitida la íntima relación entre ambas sentencias, aparece claro

(12) Cf. Denzinger-Hunerman, $N^{\text {os }} 870-875$. 
su sentido, en cuanto las palabras "omni humanae creaturae" se refieren a "todo hombre", no a "omnis potestas", como alguien llegó a afirmar (13).

Al margen de la polémica que siempre ha desatado esta bula, podemos distinguir en ella las siguientes afirmaciones:

a) A la Iglesia, en cuanto órgano universal y necesario de salvación, pertenecen las dos espadas, la espiritual y la temporal; la diferencia radica en la forma como sean usadas;

b) Si por este capítulo se reconoce una distinción entre el poder civil y el eclesiástico, se da, sin embargo, una subordinación de aquel a este;

c) Tal subordinación tiene lugar en que 1) la autoridad secular tiene su origen en la Iglesia; 2) debe conducirse por indicación y consentimiento del sacerdote; 3 ) la potestad espiritual juzga los actos de la potestad temporal.

Los textos sirvieron tanto a los defensores de la potestad directa como a los de la potestad indirecta, para fundamentar sus respectivas posiciones.

La moderna investigación ha logrado aclarar la doble confusión existente entre los términos "Imperium” y "Regnum”, que erróneamente han sido estimados como sinónimos.

El "Regnum" se refiere al poder secular, civil; el "Imperium" expresa la función protectora del poder secular en favor de la Iglesia, y comporta dos facetas:

1. El deber de la autoridad civil de salvaguardar los máximos valores de la comunidad humana (=valores religiosos y espirituales), incluso en el ámbito territorial de la propia jurisdicción civil;

2. Circunstancias históricas hacen necesaria la insistencia de otro aspecto, propiamente eclesiástico: en la medida en que el Estado olvidara sus deberes para con la Iglesia, esta debía hacer uso de su propio poder defensivo, haciéndose consciente de él y ejerciéndolo mediante laicos.

El "Imperium" viene a ser, pues, la delegación de las prerrogativas jurisdiccionales coactivas eclesiásticas, para la defensa material de toda la Cristiandad, es decir, la Iglesia y su cabeza visible, el Papa. Al entregar el "Imperium" a un príncipe, la Iglesia le daba poder para ocuparse con su brazo de los intereses eclesiásticos en todas partes. De aquí nace la confusión al otorgar la Iglesia una jurisdicción que era suya.

Este vendría a ser el sentido de la alegoría de las dos espadas en San Bernardo y en Graciano: entregar la espada material, significa entregar el propio y máximo poder coactivo para que sea ejercido en beneficio de los intereses eclesiásticos (14).

Esta fase llega a su naufragio a fines del siglo XIV dando lugar al Cisma de Occidente (1378). La concordia va a llegar a través de las instancias católicas que

(13) Cf. Lo Grasso, Ecclesia et Status, Roma 1952, 211 ss.

(14) Stickler A., Sacerdozio e Regno nelle nuove ricerche attorno ai secoli XII e XIII nei Decretisti e Decretalisti fino alle Decretali di Gregorio IX, en Sacerdozio e Regno, da Gregorio VII a Bonifacio VIII, Roma, 1954, 6- 7; De Reina V., 'Los términos de la polémica Sacerdocio- Reino', en IUS CANONICUM, VI-I,153- 199. 
habían sido olvidadas (el concilio general, el emperador) en el Concilio de Constanza (1414-1418). En el Concilio de Basilea-Ferrara-Florencia (1431-1445), se pretende anacrónicamente limitar la potestad legislativa del Papa, conforme al Decretum Gratiani: esto induce a acuñar el concepto de Corpus Iuris Canonici clausum, lo que implícitamente tiene lugar con la "recepción" conciliar de la producción legislativa papal sucesiva a la innovación constitucional de 1234. El esfuerzo por limitar al Papa hace surgir un movimiento que trata de actualizar un mayor equilibrio entre los órganos de gobierno de la Iglesia universal (el "conciliarismo"). Va a quedar flotando en el aire (= ¿en el sensus fidelium?) la sensación de que el conjunto del episcopado, en comunión ciertamente con el Papa, y con apoyo de otras fuerzas decisivas de la Cristiandad, es el elemento que hace posible la renovación eclesiástica en situaciones de emergencia.

En el Concilio de Constanza se emite el decreto "Frequens "(15), que ordena la periodicidad de los concilios generales, lo que da lugar al concilio de Basilea (1431), transferido a Ferrara y a Florencia, etc. (cf. Historia de la Iglesia), con resultados escasos, entre ellos la fracasada unión de los Griegos a Roma.

La Santa Sede se hace más cautelosa para proceder a nuevas convocaciones de concilios generales; solo al cabo de setenta años hará una convocatoria para hacer frente a la sedición de Pisa, eludiendo al mismo tiempo las insistentes peticiones de reforma "in capite et in membris", mediante un programa bastante evasivo. Baste pensar que el Concilio Lateranense V (1512-1517) no se abocó al problema de Alemania, aun cuando ya la fama de las enseñanzas de Lutero se hallaba extendida allí, sobrepasando los límites del mundo académico.

Es expresiva del clima de frustración que abrigaban los ambientes eclesiásticos frente a la renuencia para afrontar la reforma de la Iglesia, la reflexión hecha por Francisco de Vitoria: "Et ab eo tempore quo, propter novas opiniones doctorum, Pontífices inceperunt timere Concilia, Ecclesia manet sine Conciliis, et manebit cum magna calamitate et pernicie religionis" (= Y desde que los Pontífices comenzaron a temer a los concilios a causa de las nuevas opiniones de los doctores, no hay Concilios en la Iglesia ni los habrá, con gran calamidad pública y perjuicio de la religión) (16). Solamente cuando gran parte de la Cristiandad había adherido a la doctrina de Lutero (quien, en un primer momento había apelado a un concilio "libre y alemán") el emperador Carlos V logra presionar decisivamente al papa Pablo III para que convoque en Trento un concilio de reforma. Dicho concilio falló en cuanto a lograr la unión de los reformadores, aunque significó gran avance en el campo dogmático (17) y eficaz en el plano de la reforma disciplinar. Los decretos tridenti-

(15) Concilium Constantiense, sessio XXXIX (9-oct.-1417), Decretum "Frequens generalium conciliorum", en Conciliorum Oecumenicorum Decreta, Bologna,1991, 438-442)

(16) Relección De la potestad del Papa y del Concilio (año 1534). Proposición vigésima in fine, en Obras de Francisco de Vitoria, B.A.C., Madrid, 1960, 485.

(17) Es interesante traer a colación aquí, aunque sea de paso, el sentir de un buen exponente de la doctrina de la Reforma y reconocidamente poco afecto a la Iglesia Católica: "el decreto sobre la justificación, aun cuando no es una obra surgida espontáneamente, desde muchos aspectos acusa excelente elaboración; incluso uno puede preguntarse si la reforma protestante se habría desarrollado si tal decreto hubiera sido emanado por el concilio (V) de Letrán al comienzo de ese siglo y se hubiera transformado en savia y en sangre de la Iglesia" (Harnack, Dogmengeschichte, III, 711, citado por Jedin, Historia del concilio de Trento, vol.II, 1962, 357 ss.). 
nos van a constituir la veta unitaria de la disciplina católica y el núcleo del derecho canónico de la edad siguiente, que se abre con la separación de los protestantes y de los anglicanos de la unidad de la Iglesia latina.

\section{LOS DESAFÍOS DE LA ÉPOCA MODERNA Y CONTEMPORÁNEA}

\section{El derecho tridentino}

El rigor dogmático y pastoral del concilio de Trento detuvo la irrupción protestante y puso en ejecución no solamente una tendencia en sentido opuesto, sino que estimuló el movimiento misional en el lejano Oriente, gracias al concurso de una nueva orden religiosa ferviente, culta y disciplinada: la Compañía de Jesús.

El derecho tridentino impuso, entre otras, la obligación de residencia a los obispos y demás prelados investidos con beneficios anexos a la cura de almas y prohibió su acumulación; además reformó la liturgia sacramental e intervino, no sin viva oposición, en la celebración del matrimonio, prohibiendo los matrimonios clandestinos, etc.

Los principios emanados de esta legislación configuraron decisivamente los cuatro siglos siguientes, modelando la vida interna de la Iglesia. Surgen numerosas colecciones de fuentes papales (=los Bularios), que tienen carácter privado; el conocimiento de la aplicación capilar de la reforma tridentina -así como de las dificultades halladas para su recepción- se obtiene a través de las resoluciones de los dicasterios más importantes de la Curia Romana, publicadas como colecciones (SS. Congregaciones del Concilio, de Ritos y de la Propagación de la Fe).

La tormenta levantada por el protestantismo aconsejó más bien reforzar el antiguo derecho universal, antes que desarrollar un legítimo derecho particular territorial. Con todo, el concilio, previendo la dificultad para la aceptación de algunos de sus decretos más novedosos -como era el "Tametsi", acerca de la forma canónica para celebrar el matrimonio-, impuso para su efectiva vigencia en las diversas localidades, la necesidad de que fueran promulgados allí, fijándolos en las puertas de las iglesias parroquiales. Como una suplencia tutelar del derecho particular local, apareció por entonces la práctica del placet real que, especialmente en el siglo XVIII, se extendió paralelamente al absolutismo monárquico y consiguió reforzar, a menudo en manos de monarcas irreligiosos del todo, un derecho majestático circa sacra que venía a renovar, en signo inverso, la antigua teocracia de la cristiandad medieval (18). La confrontación con los absolutismos modernos y sus pretensiones de derechos reales sobre las cosas sagradas, vino a culminar cuando lograron doblar la mano al pontífice Clemente XIV para que decretara la disolución universal de la Compañía de Jesús (1773).

(18) El papa Pío IX advertirá en su oportunidad al Arzobispo Valdivieso, de Santiago de Chile, que el origen de tal placet real arrancaba de una facultad que Alejandro VI concedió a ciertos Prelados locales -jamás a autoridades laicas- para revisar las Bulas pontificias que otorgaban indulgencias, a fin de velar por su autenticidad y evitar la difusión de falsas Bulas papales. (Cf. Retamal F., Chilensia Pontificia, vol. I, tomo I, 511). 
Las dificultades empezaron a amainar con la Revolución Francesa y por la energía de Pío VII, que enfrentó el problema de la constitución civil del clero en Francia y logró el control sobre el derecho y la jerarquía locales (=la iglesia galicana), mediante el concordato con Napoleón (1801).

Con el siglo XIX se abría una nueva época en la cual la tutela de los derechos civiles, proclamada por las revoluciones burguesas contra los regímenes absolutos, significó una inesperada ayuda para la actividad de la Santa Sede, que se encontró en posibilidad de negociar -mediante concordatos posnapoleónicos- condiciones nuevas de actuación para la Iglesia.

Por otro lado, la creciente secularización de los centros universitarios europeos llevó a la Santa Sede a centralizar en Roma grandes Institutos de formación e investigación religiosa, donde se formaban los cuadros eclesiásticos, con la especial cooperación de la Compañía de Jesús, restaurada por Pío VII en 1814.

Por su parte el pueblo cristiano, anclado culturalmente en sus raíces agrarias de las cuales la revolución industrial comenzaba a sacarlo, advertía la necesidad de identificarse en un principio espiritual unitario, en torno al cual estrechar filas para enfrentar al mundo secularizado e incrédulo; este, por su parte, infatuado por los mitos del progreso, daba por indudable el cercano desaparecimiento de la Iglesia, mirada como una anacrónica supervivencia medieval, tan pronto como Napoleón III y los Saboya se decidieran a liquidar las vallas que impedían la anexión de Roma al nuevo reino de Italia.

En tan complejo contexto, Pío IX supo captar con fino tacto político, las condiciones para una nueva centralización en torno al Papa, que la conciencia eclesial, empezaba a advertir como algo inevitable y beneficioso. El Syllabus y la encíclica Quanta cura (1864) significaron un duro, orgánico e indiscriminado ataque doctrinal contra ese nuevo clima liberal y antieclesiástico. Siguió un desencadenarse de la intransigencia ultramontana contra los católicos liberales y otras corrientes intelectuales que de cualquier manera se manifestaran, dispuestas a una política de diálogo y de mediación cultural con el mundo moderno.

Una ruptura tan radical con las ideas contemporáneas no podía detenerse a mitad de camino, tranquilizada por la amplia aprobación recibida y por la represión de los opositores internos (este era, sobre todo, el verdadero nudo que había que romper, provocando un salto cualitativo institucional que pusiera definitivamente a los laicos bajo el total control del clero y rechazando cualquier concesión al pensamiento y a la cultura moderna y a la autonomía de lo temporal).

La ocasión era ciertamente favorable para confirmar sin apelación el papel del pontífice romano ante la dura realidad de un mundo que no era ya la Cristiandad y donde la incredulidad se difundía siempre más en los ambientes cultos y dirigentes.

Cuando se abrió el concilio Vaticano I en este clima (8-dic.-1869), la asamblea se dividía en dos sectores: -una, bajo el signo de la afirmación de la autoridad; -la otra, en la que se contaban las mentes teológicas más lúcidas de entonces- tendía a reevaluar las fuentes de la communio primitiva, en búsqueda de los orígenes profundos del misterio de la Iglesia.

El debate acerca de la infalibilidad papal duró menos de dos meses y concluyó con la promulgación de la constitución "Pastor aeternus" que sancionaba el dogma 
de la infalibilidad y del primado jurisdiccional del pontífice romano. No fue posible equilibrar la eclesiología del concilio, con la atención a los demás aspectos de la Iglesia, incluida la colegialidad episcopal; como es bien sabido, los trabajos del concilio tuvieron que ser bruscamente interrumpidos por la entrada en Roma de las tropas piamontesas.

De este modo quedaban establecidas las bases de una modificación del status generalis Ecclesiae, de la cual la institución papal iba a extraer el fruto más maduro en el curso de la evolución sucesiva.

\section{La codificación del centralismo papal}

Con el Derecho tridentino la Iglesia había cualificado de modo congruente su misión propia en un marco de referencia completamente nuevo con respecto a la unidad de fe de la Cristiandad medieval. Su doctrina enseguida no había dejado de estrechar positivos vínculos con el nuevo mundo en una perspectiva de gradual superación de las mutilaciones más penosas de la poderosa síntesis precedente (v.gr. baste pensar en la original transformación de la teoría de la potestas directa in temporalibus).

En cambio, se halla poquísima creatividad en el siglo XIX; con el ataque de Roma a la civilización moderna, ninguna capacidad de ofrecer esperanza, a no ser en total sumisión a la inapelable sentencia de un poder autoritario y centralizado.

Por otro lado, en sus manifestaciones más altas y coherentes, las posiciones de pensamiento fríamente desatendidas por la iglesia jerárquica -la primera de ellas, la libertad de conciencia, condenada en el Syllabus como “libertas perditionis"-, mostraban no pocas veces impreso, a partir de su prototipo Giordano Bruno, el sello inquietante de la aceptación motivada del martirio, vivido como experiencia suprema de salvación de la propia conciencia auténtica y -mirando más lejos- de la de sus perseguidores. ¿Cómo admirarse, entonces, por el imprevisto resurgir de un deísmo en forma gnóstica como camino activo de perfeccionamiento personal? Y como alternativa, ¿qué significado atrayente podía a la larga significar a la inteligencia siempre más adulta, un depositum fidei representado en la forma infantil de los catecismos del ochocientos?

Un historiador del Derecho, desde su propia perspectiva, solamente puede comprobar que la ocasión del Vaticano I fue importante para impulsar aquel movimiento favorable a un reordenamiento del derecho de la Iglesia, que condujo, al cabo de un tiempo, al encargo conferido por Pío X a Pietro Gasparri (1904) de presidir la preparación de un Código de Derecho Canónico que se insertara en la tradición de metodología legislativa inaugurada por el Código de Napoleón. Contemporáneamente, tal encargo iba a la par con la condenación casi contextual del modernismo y a la extensión de la forma tridentina de contraer matrimonio a todo el orbe católico, con los decretos, respectivamente, Lamentabili y Ne temere (1907). Eran estos, signos inequívocos de una estrategia encaminada a consolidar institucionalmente una Iglesia "reunida como una milicia obediente" en torno al Papa, en la que sonaba como debilidad e indisciplina el pluralismo que había sobrevivido a la aplicación del concilio de Trento o aquel otro que se había insertado entre las redes de la división de la cristiandad "por naciones" (oficializada en la asamblea de Cons- 
tanza), y que se había formado sobre la base de la aplicación equitativa del derecho común canónico, con el trasfondo de las incertidumbres acerca de la recepción o acerca de la vigencia de este último.

A este respecto, hay que tener presente que la disminuida eficacia unificadora del Corpus iuris canonici se debía en realidad a un doble efecto: - la aplicación de los decretos tridentinos, mediada con dúctil energía por los correspondientes dicasterios de la curia romana; y -por la difusión de un derecho local nacional, bajo la influencia de las doctrinas regalistas. De este modo, los prácticos terminaban por situar al derecho antiguo como a una fuente supletoria o, por lo menos, de segundo grado, con respecto al derecho moderno, aplicando con bastante laxitud la sentencia "jus particulare derogat generali" (un poco como sucedía con respecto al Corpus iuris civilis por lo tocante al droit coutumier). Sobre tal trasfondo-conviniendo además en que por aquí o por allá había conflictos entre la Sta. Sede y los episcopados nacionales sobre el problema de legitimar el derecho local- no era fácil dilucidar con claridad si acaso y en qué forma una disposición del derecho antiguo debiera, en un determinado contexto, tenerse como definitivamente obsoleta.

Empezaban a delinearse paulatinamente los presupuestos ideológicos para un ordenamiento universal de las fuentes jurídicas, rigurosamente unificadas, que tan útiles se habían mostrado para consolidar los estados nacionales nacidos con la Revolución Francesa. Por tal motivo, la legislación parcial que mientras tanto surgía anticipando estos contenidos (=piénsese en la constitución Sapienti consilio (1908), que reorganizaba la curia romana), era apenas un bosquejo en comparación con la audacia del proyecto mencionado.

\section{El Código Gasparri}

Gasparri fue la mente lúcida del Código, que se preparaba con la finalidad característica de los códigos revolucionarios, de debilitar definitivamente el fenómeno del envejecimiento, expresión especialmente incisiva de la tradicional relación entre ley y recepción popular. La verdad es que caracterizar con el atributo de "claridad" la técnica de las codificaciones modernas, como sigue haciéndose en muchas partes, constituye una operación ambigua. Sucede de hecho que el incluir indistintamente las fuentes en una masa dividida por numeración sucesiva -clara solamente para los que trabajan en ella- equivale a computarizar el material jurídico que tiende a la máxima abstracción de la regla con respecto a la praxis, separando el momento del conocimiento de aquel otro de la experiencia del derecho y, sobre todo, obstaculizando aquella selección cualitativa de las leyes en bien de la comunidad, que es el objeto específico del fenómeno de la recepción popular: es prueba de este intento consciente el cambio de las técnicas de la promulgación del derecho papal, con el comienzo de la publicación de Acta Apostolicae Sedis, verdadera gaceta oficial de la monarquía pontificia (1909).

La acentuada transformación del sistema de las fuentes de producción, que se estaba preparando, asumía despreocupadamente las técnicas más avanzadas del reordenamiento legislativo; pero solamente un observador superficial habría podido definirla como contraria a un neto y global rechazo del mundo moderno por parte del magisterio papal. 
La verdad es que a Gasparri no se ocultaba la profunda continuidad, que ya había descubierto Tocqueville, entre el absolutismo del Ancien Régime y los ordenamientos de la revolución cuya superior perfección, en términos de centralización jurídica, se fundaba sobre la coherente aplicación de la ideología de la "volonté genérale", lo que implicaba la concentración de un poder legislativo omnipotente en las asambleas parlamentarias. Tal concentración se cambiaba con la concesión al pueblo de la posibilidad (en verdad no muy amplia, en la práctica) de participación política, además que con una robusta tutela jurisprudencial de los derechos individuales contra las eventuales arbitrariedades del Poder Ejecutivo.

El código canónico de 1917 aparece como un verdadero monstruo políticoconstitucional frente a las codificaciones liberales-democráticas: acoge integralmente el principio formal de la indiscutible soberanía del legislador -que hacía a los regímenes de derecho burgués más eficientes que los de las monarquías absolutas-, pero no el de la participación política y del sistema de los derechos.

El primado de la ley pontificia quedó, de este modo, reforzado copiando al sistema francés, tanto la técnica de la referencia al legislador (=con la Pontificia Comisión para la interpretación del C.I.C.) como el control ejercido sobre la jurisprudencia válida, por violación de la ley, tomada de la Court de cassation (=mediante ampliación de las atribuciones del Supremo Tribunal de la Signatura Apostólica). En cambio, faltó cualquier concesión al sistema de tutela -por lo demás bien conocido al legislador canónico- del Conseil d'Etat francés.

El CIC fue promulgado en mayo de 1917 para entrar en vigencia el día de Pentecostés del año siguiente, 1918.

A partir de entonces se enraizaron en la doctrina fuertes dinámicas iuspositivistas, con notable desmedro de la producción consuetudinaria; en tanto que la jurisprudencia se preocupaba casi exclusivamente de los temas matrimoniales, frente a la exorbitante actividad de la Pontificia Comisión intérprete. De tal manera, a diferencia de lo sucedido con el derecho clásico, el Codex no recibió una actualización doctrinal y jurisprudencial, por cuanto la Curia prefirió mantener la aplicación bajo constante control discrecional, aunque a nivel de alta administración, de los mismos dicasterios centrales, que de este modo pudieron eludir los límites fijados por Benedicto XV para su actividad reglamentaria; así se llegó a ulteriores vaciamientos de la certeza del derecho, avalando en cierto modo la tesis, extrema en verdad, de quien ha sostenido que en el derecho canónico no es posible configurar la categoría de derecho subjetivo.

\section{Fuentes no incluidas en la unificación codicial}

Se excluyeron de la unificación codificada del derecho de la Iglesia las normas litúrgicas, las observadas por las comunidades católicas de ritos orientales ("uniatas") y las disposiciones de los concordatos vigentes.

Además, los obispos recibieron la facultad de tolerar las costumbres seculares contrarias al código, cuando no fuera posible desarraigarlas del todo; se condicionó la instauración de futuras costumbres, aunque fueran praeter legem (= "extra-jurídicas").

Una vez reforzado el control de la Curia sobre la producción jurídica de las instancias locales, la desautorización de estas hizo más frecuente su gestión a través 
de las nunciaturas y la regulación de los asuntos de interés interdiocesano, con irregular desplazamiento de la actividad del gobierno central hacia la periferia, en desmedro de la autoridad de los obispos locales.

En este cuadro de férrea centralización, quedaba una posibilidad teórica de acudir a la legislación conciliar; pero el largo intervalo (casi un siglo) entre uno y otro concilio vaticano, empezaba a hacer creíble la opinión de que después de la "Pastor aeternus" difícilmente habría nuevas convocatorias de concilios en la Iglesia.

En conclusión, a la hora de hacer un balance sobre la adopción de las modernas técnicas de la codificación en el ordenamiento canónico, no podría dejarse de concordar en que "el código, aun cuando en gran medida conservaba el derecho precedente, llevaba a una rígida división entre historia y derecho, mucho más de cuanto jamás se había verificado antes. En la historia de la Iglesia nunca una legislación había absorbido completamente toda la disciplina anterior y abolido formalmente todas las colecciones anteriores. El código sí lo hizo por primera vez y de ahí el resultado, ciertamente no buscado, de la separación entre historia y derecho vigente que hoy se puede comprobar, salvo pocas, aunque notables excepciones, en la enseñanza y en la aplicación práctica del derecho canónico”. (S.Kuttner) (19).

\section{El Concilio Vaticano II}

El siglo que divide el primero del segundo Concilio Vaticano vio entre laboriosas tentativas de nuevos análisis y reacciones de rígido repliegamiento, madurar lentamente el paso a una nueva fase cultural, cuyo paréntesis de finales del pontificado de León XIII representó una primera señal de inteligente apertura, lamentablemente seguida casi de inmediato por el endurecimiento provocado por el choque antimodernista.

El período de inculturación de los nuevos valores coincide sustancialmente con los tres pontificados consecutivos de Benedicto XV, Pío XI y Pío XII; pero de ningún modo puede decirse que la incubación de lo nuevo haya aportado algún fruto en el plano político-jurídico del período entre las dos guerras. Y esto es tan cierto, que el período álgido del así llamado juridicismo aparece radicado a finales del pontificado de Pío XII, con la fuerte arremetida antimodernista (enc. Humani generis, año 1950) y con la intensificación de las censuras del Indice (cf. el caso Congar y otros).

Casi como una confirmación del principio del sincronismo de las instituciones invocado por Le Bras, que enseña a encuadrar siempre el gobierno eclesiástico en el conjunto de las organizaciones políticas y administrativas del tiempo, se dio el caso de que solamente después del resultado victorioso de la guerra contra los regímenes totalitarios, han comenzado a madurar condiciones concretas de practicabilidad de un proceso de renovación hasta entonces relegado en el cerrado mundo del claustro o de las facultades de teología, bajo la capa de silencio impuesto a sus autores, que los nuevos tiempos desde decenios ya venían prefigurando.

(19) Discurso en la solemne conmemoración del 50 aniversario del Código Pío Benedictino, $27-$ mayo-1967, en presencia del papa Pablo VI (Cf. Revista Española de Derecho Canónico, 1968, 301-314). 
Como se ha dicho con razón, en este punto "solo faltaba el hombre dotado de autoridad suficiente, pero sobre todo de fina sensibilidad, para traducir en acto todo este potencial y revertir los modelos acostumbrados en vista de un más fecundo resultado, para bien de la Iglesia y del mundo entero". Y puesto que para lograrlo era menester remover situaciones incrustadas, romper lentitudes, quebrar la resistencia de intereses y costumbres inveteradas de tenacísimos centros de poder, con serena entereza Juan XXIII provocó consternada sorpresa anunciando al colegio de cardenales, reunido en la basílica de S. Pablo el 25 de enero de 1959, para la fiesta de la conversión del apóstol, su intención, absolutamente inesperada, de convocar cuanto antes un Concilio. En este anuncio aparecía ya implícita la advertencia que de allí a poco el Papa iba a dirigir a los "profetas de calamidades", para quienes tal convocatoria planteaba la visión de un cisma entre la Iglesia y el mundo (20). Se presentaba así inesperadamente una nueva situación para la misión de la Iglesia; y, por consiguiente, la invitación a una renovación interna que la situara adecuadamente a nivel de las nuevas responsabilidades que habrían de configurarse en el nuevo horizonte pastoral que se abría ante sus pasos. Al mismo tiempo significaba una confirmación de la confianza eclesial en la permanente actitud del episcopado, mediante el instituto conciliar, para proveer a las exigencias de reforma eclesiástica, pero era también un cambio importante de tendencia en la evolución misma del papado que, al cabo de cuatro siglos de tenaz conservadurismo, por primera vez tomaba la iniciativa de ponerse a la cabeza de la renovación.

\section{El Concilio como innovación política}

Mucho se ha escrito acerca del carácter "pastoral" que asumió la convocatoria del concilio; al parecer, tal calificativo viene a recapitular el dato doctrinal y el disciplinar históricamente sedimentados, en función de la tarea de decantar y reelaborar críticamente que se confiaba a la asamblea conciliar.

En el Vaticano I una de las preocupaciones principales del episcopado era colocar en el centro de la Iglesia -gracias a la proclamación del primado de jurisdicción e infalibilidad papal- un poder fuerte, capaz de resistir los embates de los regímenes liberales de entonces. En cambio en el Vaticano II, se instaura un nuevo modo de reencuentro con el mundo contemporáneo, a partir de una reflexión acerca de la naturaleza misma de la Iglesia y de su misión propia.

En tal perspectiva, el calificativo de "pastoral", a medida que transcurre el tiempo confiere mayor solidez al magisterio conciliar, de tal manera que se llega a atribuirle un significado eclesial global en el pensamiento del papa Juan XXIII, "tale da costituire senza ombra di dubbio il livello supremo della vita della Chiesa” (Alberigo).

(20) “..nos parece necesario decir que disentimos de esos profetas de calamidades que siempre están anunciando infaustos sucesos, como si fuese inminente el fin de los tiempos. En el presente orden de cosas, en el cual parece apreciarse un nuevo orden de relaciones humanas, es preciso reconocer los arcanos designios de la Providencia divina que, a través de los acontecimientos y de las mismas obras de los hombres, muchas veces sin que ellos lo esperen, se llevan a término, haciendo que todo, incluso las adversidades humanas, redunden en bien para la Iglesia". (Homilía en la inauguración del Concilio, 11-oct.-1962, n.10). 
Conocidos canonistas como Gismondi, propician un "reenvío" a la totalidad del magisterio conciliar (21); con todo, el precepto que dispone la canonización en bloque de los principios constitutivos del concilio viene a ser en realidad un poder constituyente, que se desarrolla en la Iglesia para su sana reforma.

\section{La "communio "como régimen eclesial}

El Sínodo episcopal de 1985 destacó la nota de Comunión como medular en cuanto a la naturaleza de la Iglesia, según el magisterio del Vaticano II, lo que viene a implicar que su línea que pudiéramos llamar" política", tiene que ser la de crear, suscitar y valorizar los elementos de comunión y corregir estructuras de gobierno en búsqueda de una congruencia que sea efectivamente tal.

Por otro lado, las características del llamado conciliar al pueblo de Dios, tomadas en su conjunto, implican una movilización del corpus fidelium en la fase de recepción del Concilio mismo, que asume una importancia inédita respecto a la anterior pasividad: al pedir a los miembros de la Iglesia medirse en mayor conciencia con el depositum fidei, cuyo núcleo ha de ser asumido como motivación de fondo de su consagración a la misión de la Iglesia, para hacerse signo de salvación para el mundo. Pero con esta llamada a la corresponsabilidad ¿no contrasta acaso, todo el sistema anterior de centralización jurídica, consecuencia del Vaticano I? Planteando esta pregunta es como se llega al corazón de lo que parece ser una característica fundamental: la transición de uno a otro "status Ecclesiae", promovida por una hermenéutica crítica, atenta a la vez a los documentos y al movimiento de la historia De aquí surge una consecuencia que, enunciada brevemente, viene a significar que el tránsito a un régimen de comunión plenamente desplegado es exactamente la forma de existencia que la Iglesia Católica ha asumido "con propia y consciente determinación sobre su concreto modo de ser", a la luz del Vaticano II.

\section{Los "principios segundos" de la reforma}

Al pleno desplegarse del principio de comunión se añade correlativamente, como vimos, el término de aquella condición de pasividad en la cual -bajo el anterior régimen- se hallaba constreñida la mayor parte de los sujetos del ordenamiento canónico: tiende, en consecuencia, a delinearse un área de corresponsabilidad pastoral siempre más difundida.

Esto conlleva opciones garantizadoras que sean congruentes -es decir, que consideren la ampliación del ámbito de los fieles en equiparación con los deberes correspondientes- en una doble dirección: -ante todo, una más clara y definida inmunidad de la esfera subjetiva, frente a la eventualidad de ilegítimas invasiones prohibidas incluso al poder jerárquico; y -creación de áreas de intervención activa en el ámbito social y de participación directa en la misión de la Iglesia, de parte de cada uno o en forma comunitaria.

(21) Gismondi Pietro, I principi conciliari e il Diritto Canonico, en Il Diritto Eclesiástico, LXXIX (1968), 3- 21 . 
Sobre tal trasfondo conjunto ha habido quienes (Gismondi, Lombardía) han delineado algunas líneas principales de tutela:

a) la dignidad y la libertad del cristiano como condición connatural a la pertenencia al pueblo de Dios, con todas las consecuencias previsibles en el plano de la evidencia primaria de los derechos/ deberes fundamentales del fiel;

b) la igualdad fundamental de los fieles y orgánicamente (según las vocaciones o las funciones ejercidas) su corresponsabilidad solidaria en la edificación de la Iglesia;

c) el reconocimiento de la doctrina acerca de los carismas (cf. Lumen gentium,12; Apostolicam actuositatem 3), con la afirmación inequívoca del necesario discernimiento jerárquico y del derecho/deber de su ejercicio para bien de la comunidad de la Iglesia;

d) la doctrina de la sacramentalidad del episcopado y del vínculo de comunión jerárquica que incorpora al colegio episcopal y la igual dignidad de todas las Iglesias, en las cuales y a partir de las cuales existe la Iglesia una, santa (Lumen gentium, 23).

Sobre la base de estas premisas se ve con claridad que el Vaticano II no se ha reducido a completar la eclesiología del Vaticano I. Ante todo, el contexto sistemático en el cual se sitúa el "complemento" -el pueblo de Dios y el sacerdocio común de los fieles- implica un horizonte más amplio que la eclesiología del siglo XIX, todavía cautelosa para valorizar aquellos temas bíblicos que habían constituido el meollo de la crítica luterana a la doctrina de Trento acerca de los ministerios.

Aun admitiendo que algunos elementos de esta nueva visión eclesiológica se habían hecho parcialmente presentes con anterioridad (cf. Encícl. Mystici corporis, de Pío XII (29-jun.-1943), la persistente juxtaposición de dos eclesiologías que se mostraban irreductibles entre sí, no habría encontrado nunca un principio de solución sin una intervención concreta del poder constituyente dirigido a trasladar el centro de gravedad eclesial del eje del oficio jerárquico al de la comunidad: precisamente en esta perspectiva más amplia y rica, es dado apreciar en su verdadera dimensión los valores y aportes del pasado.

Ha sido, en una palabra, esta intervención normativo-pragmática la que logró soltar un nudo teológico de otro modo insoluble: al mostrar el valor que debía privilegiarse en la opción fundamental decidida por la asamblea sinodal en comunión con el pontífice romano.

\section{Los principios y la técnica de la recepción}

Consecuencia de la opción fundamental realizada por el poder constituyente $-y$ difícilmente separable de ella- era el reforzamiento de los factores capaces de modificar el equilibrio de la constitución material, a fin de secundar la transición de uno a otro status generalis ecclesiae, conforme a líneas de evolución programada que debían recorrerse por sucesivas etapas.

Esta ha sido la gran tarea emprendida por Pablo VI, al hacer entrar en funcionamiento el sínodo de los obispos, la notable consolidación de las conferencias episco- 
pales, el lanzamiento de mecanismos de colegialidad diocesana destinados a sustituir el cabildo catedral, la reforma del Santo Oficio, perseguida no solamente a través de limitaciones y garantías frente a su actividad inquisitorial, sino con la intención de una profunda transformación cultural acerca del papel que corresponde a dicho dicasterio.

¿Código o Concilio?

Aun cuando el proyecto de un futuro Concilio y la reforma del C.I.C. aparecieron unidos en la propuesta de Juan XXIII, hay quien piensa que la vaguedad de la segunda proposición (=reforma del C.I.C.) haya sido conscientemente señalada de ese modo, a fin de dejar la mano libre al Papa para sus planes de renovación, en caso de que el futuro Concilio no los asumiera en forma suficiente.

Parece admisible la idea de que la revisión del C.I.C. de 1917 se inscribía en la polémica -genérica pero eficaz- contra el juridicismo: tal polémica habrá hallado una cierta sintonía con la sensibilidad pastoral de Juan XXIII. No hemos de olvidar que los Papas "pastorales" del siglo XX -S.Pío X y Juan XXIII- fueron los propulsores de la renovación del ordenamiento canónico. Juan XXIII no alcanzó a echar a andar la Comisión Pontificia para la reforma del C.I.C. Fue tarea de Pablo VI darle forma e impulsar la actuación de las resoluciones conciliares mediante una legislación papal experimental y provisoria: estos pasos fueron delineando con claridad la superación del proyecto inicial que Juan XXIII había considerado solamente como una recognitio (=revisión).

Al poco tiempo de terminado el concilio, el primer sínodo de los Obispos (1967) aprobaba los principios directivos que debían presidir la elaboración de un nuevo Código de Derecho Canónico.

\section{Indicaciones hermenéuticas de Juan Pablo II}

El nuevo CIC promulgado por Juan Pablo II ha encontrado resistencia en algunos sectores, especialmente en el hemisferio norte que, a pesar de su buena voluntad, no creen hallarse ante la mejor ejecución posible del Concilio Vaticano II. Justamente preocupado por perspectivas tan poco promisorias en cuanto a la acogida de la codificación, el Papa quiso desde el comienzo impulsar la recepción con algunas intervenciones equilibradas, dirigidas a poner en claro la "ratio legis" de la legislación papal formalizada en el nuevo código y su decidida subordinación hermenéutica al Concilio: esto último ha sido recalcado con insistencia, en cuanto a leer el código en paralelo con el concilio, de modo que la "lex nova" llegue a encontrar siempre, en cuanto es posible, su esencial referencia en la imagen de la Iglesia-comunión, reflejada en la Lumen gentium (22).

(22) "El Código es un instrumento que se ajusta perfectamente a la naturaleza de la Iglesia, sobre todo tal como la propone el magisterio del Concilio Vaticano II, visto en su conjunto, y de modo especial su doctrina eclesiológica. Es más: en cierto modo, este nuevo Código puede considerarse como un gran esfuerzo por traducir en lenguaje canónico esa misma doctrina, es decir, la eclesiología del Concilio. Porque, aunque no sea posible reproducir perfectamente en lenguaje "canónico" la imagen de la Iglesia descrita por la doctrina del Concilio, el Código, sin embargo, habrá de referirse siempre a esa imagen como a su modelo original, y reflejar sus líneas directrices, en cuanto sea posible a su propia naturaleza" (Bula "Sacrae disciplinae leges" (25-enero-1983), promulgatoria del C.I.C.). 
Sobre el trasfondo de tales aperturas y teniendo presentes los notables espacios de autonomía legislativa reservados a la conciliaridad local y a la iniciativa pastoral de las conferencias episcopales, que en el último tiempo están llegando a ser punto de fuerza del pluralismo eclesiástico, varios conocidos canonistas (Feliciani, Lombardía) creen ver a futuro un nuevo panorama más amplio para la legislación local, incluida la forma consuetudinaria.

Entretanto, el Código aparece no como una legislación provisional y caduca, sino como la plataforma técnicamente homogénea sobre la cual las iglesias particulares están llamadas a articular juntas -desechando gratuitas tentaciones centrífugas- su específico cuadro disciplinar durante la recepción del concilio.

Además del Código continúa el proceso de transformación. Y si la tarea exige el discernimiento del Espíritu para quien ocupa cargos de dirección pastoral, propone un quehacer más modestamente técnico para el canonista, para el cual la primera exigencia que se impone parece ser librarse del mito de la codificación y de los lazos del positivismo exegético, a fin de seguir con menos reservas los imprevisibles caminos de un sistema "in fieri" que empieza a brotar y en el cual -a medida que avanza su evolución-, será siempre menos fácil reconocer el tronco germinal a quien insista en querer buscarlo fuera del proceso constituyente puesto en marcha por el Concilio Vaticano II. En otras palabras, por un acontecimiento dotado, antes que de carácter canónico, de la fuerza del Espíritu: y que gracias a ella -quiérase o no- se va haciendo sangre y médula de la Iglesia.

\section{SEGUNDA PARTE}

\section{HACIA UNA MAYOR CREDIBILIDAD DEL EJERCICIO DEL PODER EN LA IGLESIA}

\section{EL DERECHO CANÓNICO REQUIERE SER VALORADO Y APLICADO EN ESTRECHA CONEXIÓN CON EL DATO DE LA REVELACIÓN Y LA NATURALEZA MISTÉRICA DE LA IGLESIA}

El Vaticano II ha significado un cambio en el modo de concebir el derecho en la Iglesia y de captar e interpretar los aspectos fundamentales de la dimensión jurídica que caracteriza internamente a la comunidad de los fieles. Ha habido un proceso para volver a pensar desde nuevas perspectivas aspectos tan variados como la naturaleza originaria del derecho canónico, la relación que se da entre derecho divino/derecho humano, las caracterizaciones y los modos de ejercicio de la autoridad, etc. Una consecuencia de esta nueva actitud ha sido, no solamente la amplia reforma de la legislación de la Iglesia, en sus vertientes occidental y oriental, sino el descubrir nuevamente el espíritu y la específica naturaleza del derecho canónico y su profundo enraizamiento en la realidad mistérica de la Iglesia.

Esto ha llevado a tomar conciencia que el ordenamiento jurídico de la Iglesia en su origen y en su existencia, no puede ser explicado en términos puramen- 
te naturalistas o sociológicos, como podría suceder para cualquier otra comunidad humana que, por el solo hecho de expandirse y consolidarse, requiere una estructura jurídica interna. Por lo que toca a la Iglesia hay que remontarse a la voluntad de Quien, como fundador de la Iglesia, ha querido imprimirle la esencial dimensión de un "deber-ser" salvífico. Las referencias a los ordenamientos jurídicos civiles u otras experiencias comunitarias, los datos obtenidos por la experiencia o por la historia no bastan para comprender cabalmente el verdadero núcleo de una realidad jurídica que solamente puede ser concebida adecuadamente a la luz de la Revelación. Las características mismas del derecho de la Iglesia permiten concebirlo a modo de un proceso que no podría pretender jamás rigidizar en esquemas inadecuados la posición de los sujetos en el desarrollo de la historia de la salvación; dicho de otro modo, se trata de un derecho que permite someter cualquier clase de norma o de autoridad a ese núcleo último constituido por el mandamiento de la caridad evangélica, es decir, por el respeto a cada persona, imagen de Dios. A raíz de lo dicho recién, aquí hay que tener presente aquellos factores característicos de la legislación canónica, que hacen posible una gran flexibilidad y adaptación de una norma a las situaciones concretas en un determinado momento,y que constituyen medidas correctivas, nacidas ya en el derecho clásico (piénsese, por ejemplo, en la equidad canónica, la remonstratio, la dispensa o la epikeia); de este modo, para mantener la dimensión del deber-ser (= "lo justo" o "lo debido") en un caso particular, es eventualmente posible una legítima exención a la ley general. Cuando se habla de la necesaria pastoralidad del ordenamiento jurídico de la Iglesia, ha de advertirse su finalidad en servicio del bien espiritual de los fieles, formulada simbólicamente en el último canon del Código vigente: “...prae oculis habita salute animarum, quae in Ecclesia suprema semper lex esse debet”(can.1752).

\section{LA DIGNIDAD PERSONAL DE CADA FIEL CRISTIANO. DERIVACIO- NES JURÍDICAS DE SU CONDICIÓN BAUTISMAL}

En este proceso de redescubrimiento y valorización de la dimensión jurídica de la Iglesia hay que mirar a dos elementos que caracterizan, en sí mismos y en relación recíproca, el orden institucional de toda experiencia comunitaria: la autoridad y la libertad. Por un lado, la instancia de gobierno, con indicaciones imperativas y obligatorias; por otro, la autonomía y los espacios entregados a la determinación de cada uno de los miembros integrados.

En la Iglesia, también estas dos instancias fundamentales han recibido el influjo de la doctrina conciliar del Vaticano II, con la consecuencia de un renovado contenido para cada una de ellas y para su recíproca interacción. Esto implica la valoración de la dignidad de la persona humana, cualquiera sea el ambiente o comunidad donde esté situada. En el plano más específicamente eclesial, trae como consecuencia el redescubrimiento de la vocación bautismal, como cristoconformación de cada fiel: participación en el sacerdocio de Cristo e inserción en la comunidad de salvación; todo esto ha llevado a configurar la Iglesia como pueblo de Dios, donde cada miembro se sitúa en igualdad fundamental de dignidad y común participación 
en edificar la Iglesia. De aquí ha derivado, en el plano jurídico, un estatuto fundamental del fiel cristiano, es decir, una situación jurídica subjetiva de base, común a todo bautizado, que constituye el punto de referencia y de construcción de todo el ordenamiento canónico.

Esto ha llevado a un cambio radical en la configuración del derecho canónico, tradicionalmente mirado como un derecho de talante esencialmente autoritario, instrumento para mantener la sumisión y la obediencia a los mandatos de los jerarcas, impartidos en orden a la salvación eterna. Ahora, el fiel cristiano, en virtud del bautismo y de su condición de persona en la Iglesia, aparece como el verdadero protagonista y centro referencial de la experiencia jurídica eclesial. Se reconoce en el fiel cristiano, a nivel fundamental y prioritario, un conjunto de derechos, unidos a sus correspondientes deberes, que el ordenamiento debe tutelar y promover en su actuación concreta, como momento esencial de realización de un orden social justo, proyectado hacia la salvación en Cristo.

En congruencia con esta visión de fondo, el nuevo Código latino ha revolucionado la tradicional sistemática que partía de las normas acerca de la jerarquía y le reservaba la mayor parte de las disposiciones; al final, venían las normas acerca de los fieles y los eventuales derechos/deberes concernientes. Como es sabido, el Libro II del Código, consagrado a la estructura constitucional de la Iglesia, se titula significativamente De populo Dei y comienza con un elenco de disposiciones dirigidas a los christifideles en general, con una analítica indicación de los deberes y derechos que les competen en virtud de su regeneración en Cristo mediante el bautismo.

Tal atención a la condición jurídica de cada fiel, tal esfuerzo para delinear un estatuto fundamental, que es propio de cada uno de ellos, podría aparecer a alguien como una concesión táctica de parte de la Iglesia hacia el derecho constitucional de los Estados democráticos de nuestros días (=las "garantías constitucionales") o a las solemnes declaraciones sobre los derechos humanos formuladas en diversas instancias internacionales. La respuesta, sin embargo, es otra: el magisterio del Vaticano II, con acentos agustinianos, ha reconocido la recíproca compenetración que en el curso de la historia se da entre "la ciudad terrena y la ciudad eterna, que solo puede percibirse por la fe, y es un misterio permanente de la historia humana" (G.Sp. 40 \& 3) (23). De ahí que esta particular atención al estatuto fundamental y constitucional de cada uno de los fieles, deriva de la realidad íntima de la Iglesia, tal como la doctrina conciliar la ha redescubierto y valorizado: "Este pueblo mesiánico tiene por cabeza a Cristo, ...La condición de este pueblo es la dignidad y la libertad de los hijos de Dios..." (L.G.9 \& 2). El derecho canónico no ha hecho sino traducir en categorías jurídicas las consecuencias de tal "dignidad" y "libertad" de los hijos de Dios, a fin de que no se queden en simples conceptos irrelevantes a la hora de las concreciones.

(23) En el punto que nos interesa, hay todavía un texto más directo y elocuente: "La Iglesia, por disponer de una estructura visible, señal de su unidad en Cristo, puede enriquecerse, y de hecho se enriquece también, con la evolución de la vida social, no porque le falte en la constitución que Cristo le dio elemento alguno, sino para conocer con mayor profundidad esta misma constitución, para expresarla en forma más perfecta y para adaptarla con mayor acierto a nuestros tiempos". (Const. Gaudium et Spes, 44 \& 3). 


\section{LA AUTORIDAD EN LA IGLESIA DERIVA DE LOS DATOS DE LA REVELACIÓN Y SE TRANSMITE POR VÍA SACRAMENTAL EN EL ORDEN SAGRADO. LA POTESTAD ECLESIAL ES COLEGIADA Y MINISTERIAL}

La naturaleza peculiar de la Iglesia exige, por lo tanto, el reconocimiento de una condición fundamental y constitucional de igualdad de todos los christifideles. Sobre la base de tal consagración bautismal, pueden incorporarse ulteriores caracterizaciones que, en el caso de las Ordenes sagradas, inciden ontológicamente (y no solo en sentido funcional) en la condición misma del fiel cristiano, fundamentándola en la capitalidad de Cristo. Los órganos jerárquicos en la Iglesia no son, entonces, una clase dirigente seleccionada por razón de mecanismos sociológicos o contingencias históricas, sino un dato surgido de la Revelación, que tiene su origen en la voluntad misma de Cristo, Fundador y Cabeza de la Iglesia. De este modo, solamente aquellos fieles cristianos que han sido sacramentalmente configurados con Cristo Cabeza de su Cuerpo, mediante el Orden sagrado, son hábiles para recibir y ejercer la potestad de gobierno en la Iglesia. Los demás fieles -los laicos de ambos sexos- pueden cooperar al ejercicio de dicha potestad, en todos aquellos cargos o funciones eclesiales, para los cuales no se requiere la recepción del sacramento del Orden (cf.can.129).

En el ámbito de los ordenados surge el ministerio de los Obispos quienes, "por institución divina son sucesores de los Apóstoles y en virtud del Espíritu Santo que se les ha dado, son constituidos como Pastores en la Iglesia, para que también ellos sean maestros de la doctrina, sacerdotes del culto sagrado y ministros para el gobierno" (can. $375 \&$ 1). En este mismo canon se señala enseguida que, por la consagración episcopal, junto con la función de santificar, los Obispos reciben también las funciones de enseñar y regir (ib.\& 2).

El concilio y la legislación que le ha seguido han redescubierto y valorizado algunos rasgos que caracterizan la autoridad en el ámbito de la Iglesia y han permitido recobrar su propia y peculiar fisonomía, más estrechamente derivada del derecho divino y menos tributaria de la ciencia jurídica secular. De este modo se ha insistido en la estrecha derivación de toda potestad en la Iglesia a partir de la voluntad de Cristo, expresada en la Revelación y transmitida a través de los signos sacramentales: este es el origen de la autoridad en la Iglesia y en esta voluntad de Cristo halla su más verdadera legitimación.

Esta mayor conciencia de la naturaleza revelada y de las raíces sacramentales de la autoridad ha puesto en discusión la tradicional bipartición entre potestas ordinis y potestas iurisdictionis, favoreciendo una concepción unitaria, que tiende a presentar una única y fundamental sacra potestas, conferida por Cristo a los apóstoles y transmitida sucesivamente a los obispos. Aun cuando la legislación del Código ha mantenido tal bipartición potestativa, es posible advertir allí algunas innovaciones importantes que manifiestan el influjo de la concepción unitaria y una conciencia más clara del fundamento divino de la autoridad, especialmente en lo que atañe a la consagración episcopal. En virtud de esta consagración y de la comunión jerárquica, todo obispo entra a formar parte del Colegio episcopal y 
participa así de un organismo dotado de suprema potestad en la Iglesia (can. 336); por lo mismo, y siempre en virtud de esta consagración sacramental, tiene derecho a participar con voto deliberativo en un Concilio ecuménico (can. 339 \& 1). Solamente con la consagración episcopal el que es elegido Papa obtiene la plenitud de aquella suprema y plena potestad inherente al oficio primacial otorgado por Cristo singularmente a Pedro y transmitido a sus sucesores. Si el recién elegido no fuera obispo, debe ser consagrado inmediatamente después de haber aceptado la elección (can. $332 \& 1)$.

Otra nota que caracteriza la autoridad en la Iglesia es la colegialidad: ella encuentra su máxima expresión a nivel de la Iglesia universal en el Concilio Ecuménico, pero también se presenta analógicamente en el ámbito de las Iglesias particulares y, con mayor generalidad, en toda estructura comunitaria del Pueblo de Dios: institutos de vida consagrada, asociaciones de fieles, organismos colegiados, etc.

Esta nota de colegialidad tiene entre sus consecuencias el diferenciar claramente la constitución jerárquica de la Iglesia de la estructura organizacional de los ordenamientos seculares, sin permitir superficiales paralelos ni asimilaciones a estructuras presidencialistas, parlamentarias, totalitarias u otras. A la vez, se refuerza el enraizamiento de la estructura constitucional de la Iglesia en la voluntad fundacional de Cristo (=derecho divino). De este modo se clarifica la original y específica configuración del orden institucional de gobierno en la Iglesia, que ve en el vértice a dos sujetos, dotados de potestad suprema y plena: el Papa en cuanto singularmente ostenta el ministerio de Pedro y el Colegio de los Obispos en quien descansa la misión que Cristo confiara a los Doce. Se trata de órganos de gobierno estrechamente ligados, distintos en su modo de ser y de actuar (uno es individual y el otro colegiado), que encuentran su punto de unión en la persona del Papa quien, siendo Obispo de Roma, preside necesariamente el Colegio de los Obispos y actúa al interior del Colegio, sin menoscabo de su condición individual de Sucesor de Pedro.

En un plano más operativo, el principio de la colegialidad ha dado origen al Sínodo de los Obispos, que es convocado periódicamente y colabora como órgano consultivo de máximo relieve, al gobierno de toda la Iglesia ejercido por el Papa. Basta pensar en el papel que ha ejercido en los años del postconcilio, a nivel universal o sectorial, de tal manera que para abordar en debida forma el magisterio del Vaticano II, hay que referirse a la vez a los aportes doctrinales que han significado los Sínodos Episcopales sucesivamente celebrados.

A nivel de Iglesia particular, el principio de colegialidad ha llevado a redescubrir el presbiterio, que se sitúa junto al Obispo, al servicio de la comunidad de fieles con que se constituye la Iglesia particular. No es un órgano dotado de potestad de gobierno, y en esto se diferencia del Colegio de los Obispos, sin embargo constituye un componente ineludible de la Iglesia particular y otorga al gobierno de ella una fisonomía netamente colegiada. Tal fisonomía se va consolidando en una serie de nuevos organismos e instrumentos institucionales, consejos, comisiones, colegios etc., a diversos niveles y esto ha contribuido a conferir también un sentido más colegiado a una institución tan antigua como es el sínodo diocesano. En sede de canonistas, continúa profundizándose el principio de Sinodalidad, tan desarrollado en las Iglesias Orientales, que motivara el VII Congreso 
Internacional de Derecho Canónico, en la UNESCO, París, septiembre de 1990 y cuyas actas constituyen un referente autorizado sobre esta materia (24).

Sin duda, la nota que más ha de caracterizar el ejercicio de la autoridad en la Iglesia es su connotación de existir para el servicio de los fieles. No se trata de una simple tendencia a nivel exhortativo, sino de una estructuración interior, de una verdadera dimensión ontológica requerida, también ella, por la institución originaria del mismo Cristo (Mt 20, 26 - 28). Esta dimensión ministerial halla una primera y significativa expresión en la distinción que se da entre el munus (=la función) y la potestas (=la potestad expedita para su ejercicio), y su correspondiente sistemática, que tiende a organizar todas las prerrogativas fundamentales de la autoridad en torno a tres funciones fundamentales: docendi, sanctificandi, regendi. Sin embargo, estos cambios terminológicos y sistemáticos podrían quedarse en simple maquillaje si no van acompañados de variaciones substanciales que influyan decisivamente en el comportamiento concreto de la autoridad, los moldes organizativos, las modalidades con que ejerce sus propias facultades. Es necesario que tales funciones autoritativas no sean consideradas como prerrogativas estrictamente personales ni como espacios subjetivos de libre disposición para sus titulares, ni, mucho menos, como "dignidad" personal; es la organización eclesiástica la que debe adecuarse a las necesidades de los fieles y no a la inversa ("El sábado ha sido instituido para el hombre y no el hombre para el sábado". Mc 2, 27). Por su parte, el derecho debe dar una operatividad concreta a estas notas, a fin de otorgar una efectiva dimensión jurídica a dicha ministerialidad, evitando relegarla al terreno de las exhortaciones, buenos deseos o, a lo más, al ámbito de la responsabilidad moral según la conciencia de cada uno.

En el sentido en que vamos hablando, es dado encontrar algunas concreciones significativas, como es la más amplia aplicación del principio de legalidad, según el cual el ejercicio de la autoridad administrativa está sujeto a más cuidadoso control, evitando desbordes autoritarios contrarios al efectivo bien de los fieles. Con todo, la supresión de los tribunales administrativos a nivel regional, en la fase preparatoria final, inmediata a la promulgación del actual Código, sigue siendo un interrogante abierto. Otros signos favorables son la temporalidad en los cargos de gobierno eclesiástico, tanto en las Iglesias particulares como a nivel de la Curia romana, la obligación de presentar la renuncia al límite de cierta edad y la apertura al desempeño de ciertos oficios que no requieran previamente la recepción del Orden sagrado, por parte de laicos idóneos, tanto varones como mujeres.

Al finalizar este apartado, podemos deducir que queda aún un largo camino por recorrer, a fin, de hacer verdaderamente creíble el ejercicio de la potestad en la Iglesia. Ciertamente, no es solo asunto de estructuras, sino de una conversión hacia un estilo más evangélico en el ejercicio de las respectivas funciones. Puede servir de testimonio, un texto legislativo, que se hallaba incluido en el anterior

(24) L'Annèe Canonique, Hors sèrie, La Synodalitè. La participation au gouvernement de 1'Eglise, Actes du VIIe. Congrès International de Droit Canonique, Paris Unesco, 21- 28 septembre 1990, 2 volúmenes 1992. 
Código de Derecho Canónico, promulgado en 1917, extraído a su vez del Concilio de Trento, y se refiere a la actitud de los Jerarcas eclesiásticos al momento de intimar o aplicar sanciones penales. Se trata, pues, de un momento crucial en el que es posible que se deslicen múltiples injusticias, si solo se atiende a la letra y no al espíritu de las normas penales. Constituía el párrafo 2 del antiguo canon 2214: Téngase, sin embargo, a la vista la advertencia del Concilio de Trento, sess. XIII, de ref., cap. I: "Acuérdense los Obispos y los demás Ordinarios de que son pastores y no verdugos y que conviene que rijan a sus súbditos de tal forma, que no se enseñoreen de ellos, sino que los amen como a hijos y hermanos, y se esfuercen con exhortaciones y avisos en apartarlos del mal, para no verse en la precisión de castigarlos con penas justas si llegan a delinquir; y si ocurriere que por la fragilidad humana llegaren estos a delinquir en algo, deben observar aquel precepto del Apóstol de razonar con ellos, de rogarles encarecidamente, de reprenderlos con toda bondad y paciencia, pues en muchas ocasiones puede más, para con los que hay que corregir, la benevolencia que la austeridad, la exhortación más que las amenazas, y la caridad más que el poder; mas, si por la gravedad del delito es necesario el castigo, entonces es cuando deben hacer uso del rigor con mansedumbre, de la justicia con misericordia, y de la severidad con blandura, para que sin asperezas se conserve la disciplina, saludable y necesaria a los pueblos, y los que han sido corregidos se enmienden o, si estos no quieren volver sobre sí mismos, para que el castigo sirva a los demás de ejemplo saludable y se aparten de los vicios".

\section{LA LIBERTAD COMO PRINCIPIO CONSTITUCIONAL DE DERECHO DIVINO EN LA IGLESIA}

La configuración de la autoridad en términos de servicio nos lleva a dirigir nuevamente la atención al fiel cristiano, confirmando así que él es el punto de convergencia de todo el ordenamiento jurídico de la Iglesia. En el ámbito de la condición jurídica fundamental los fieles (cf. supra 2), aparecen situaciones atinentes a la esfera de libertad que compete a cada uno. Se trata de libertades constitucionales, no derivadas de una concesión por parte de la jerarquía de la Iglesia ni derogables, pues su origen arranca de la voluntad misma de Cristo y deben su existencia concreta a la condición bautismal de cada uno.

En esta esfera de libertad, sustraída por lo tanto al poder jerárquico, hallamos el derecho al apostolado personal, es decir, a "trabajar para que el mensaje divino de salvación se difunda siempre más a los hombres de todo tiempo y de todo lugar" (can.211): esto conlleva la posibilidad de asumir todas aquellas iniciativas y actividades, en forma individual o asociada, para fines de apostolado, independientemente de algún específico mandato o delegación de la autoridad eclesiástica, dentro de los márgenes de la comunión eclesial.

En un plano más estrictamente personal, dicha libertad contiene además el derecho a una propia forma de espiritualidad, con tal de que sea conforme con la doctrina de la Iglesia (can. 214). De aquí deriva también la exigencia del máximo respeto por los carismas personales de los fieles que, en cuanto son gracias del 
Espíritu Santo, conforman de modo determinante la vida espiritual del cristiano (25). Si bien el término "carisma" no aparece tal cual en el C.I.C. de 1983, el "principio carismático "sí aparece consolidado desde el momento que la nueva legislación confiere carácter constitucional, y no meramente asociativo, a los Institutos de vida consagrada, que vienen a ser una forma institucionalizada de carismas fundacionales. Esos Institutos pertenecen... "a la vida y a la santidad de la Iglesia" (can.207 \& 2), sin olvidar que "los consejos evangélicos, fundados en la doctrina y el ejemplo de Cristo Maestro, son un don divino que la Iglesia ha recibido del Señor y conserva siempre con Su gracia" (can. 575) (26).

El derecho a la propia espiritualidad incide necesariamente en la acción pastoral, condicionando las modalidades concretas de su ejercicio; los pastores no pueden pretender monopolizar una espiritualidad específica ni imponer, directa o indirectamente, formas y medios de una determinada espiritualidad. A este respecto, Eugenio Corecco ha señalado: "La fuerza jurídica del carisma levanta una valla impenetrable al ejercicio de la 'sacra potestas' de los Pastores, a quienes corresponde no solamente la responsabilidad de juzgar la autenticidad de los carismas, sino además, y sobre todo, la de respetarlos en su derecho a existir y ser llevados a la práctica" (1.c.).

En estrecha relación con el derecho a seguir una forma propia de vida espiritual, existe el "derecho a ser inmunes de cualquier coacción en la elección del estado de vida" (can 219). Se trata, en verdad, de un derecho natural que corresponde a todo hombre, pero que en la Iglesia adquiere una significación especial, si se considera que mediante tal elección se individualiza la modalidad concreta en que se ha de vivir la vocación cristiana, ya sea como clérigo o laico, casado, célibe o consagrado a Dios.

Tanto el apostolado como la espiritualidad a menudo implican una forma asociada o comunitaria de ejercicio. De aquí nace el reconocimiento de otro derecho fundamental de libertad, que deriva de la dimensión comunitaria del pueblo de Dios: el derecho de reunión y de asociación para fines eclesiales (can. 215). En este derecho se incluye el fundar asociaciones o adherirse a las ya establecidas, el de participar en la vida de tales asociaciones, dirigirlas y gobernarlas conforme a los estatutos, el abandonarlas y, llegado el caso, decidir su extinción. Contrariamente a lo que sucede en el derecho civil, donde la asociación es un fenómeno típico de autonomía privada, en el sistema canónico una asociación asume relieve eclesial, no tanto por originarse en un proceso voluntarístico de los fieles en el ejercicio de un derecho fundamental, sino porque surge en cierto modo, del nacimiento de un carisma.

(25) "Es la recepción de estos carismas, incluso de los más sencillos, la que confiere a cada creyente el derecho y el deber de ejercitarlos para bien de la humanidad y edificación de la Iglesia en el seno de la propia Iglesia y en medio del mundo, con la libertad del Espíritu Santo, que sopla donde quiere (Jn 3,8), y en unión al mismo tiempo con los hermanos en Cristo, y sobre todo con sus pastores, a quienes toca juzgar la genuina naturaleza de tales carismas y su ordenado ejercicio, no, por cierto, para que apaguen el Espíritu, sino con el fin de que todo lo prueben y retengan lo que es bueno" (cf. I Thess 5,12.19.21). (Decr. Apost. Actuositatem, 3 \& 4).

(26) Corecco E., Istituzione e carisma in riferimento alle strutture associative, en Das Konsoziative Element in der Kirche. Akten des VI Internationalen Kongresses für kanonisches Recht, Munchen, 1989, 79-98, espec. 94 ss. 
Por último, hay que mencionar el derecho a la libertad en materias de orden temporal que el legislador, por una defectuosa sistematización de los cánones, asigna a los fieles laicos (can. 227) (27), pero que en realidad es propio de todo fiel, cualquiera sea su ulterior condición eclesial (=clérigo, vida consagrada...), cada vez que deba actuar a título personal en asuntos temporales. Esto deriva de la autonomía misma de las realidades temporales con respecto a las espirituales y a la consiguiente ausencia de vínculo jurídico de dependencia de las realidades terrenas con respecto a la Iglesia. El fiel cristiano cuando actúa en el ámbito de estas realidades, no está jurídicamente vinculado a la Iglesia; las opciones que haga tocan a su autonomía y responsabilidad personales y no pueden ser objeto de medidas jurídicas, coercitivas o discriminatorias, por parte de los superiores jerárquicos. Con todo, se da el derecho a intervenciones jerárquicas en asuntos doctrinales (28) y la respectiva obligación moral de acatarlas, por parte de los fieles.

El derecho de libertad en materias temporales, reconocido a nivel eclesial, encuentra una correspondencia en el derecho de libertad religiosa que compete a la Iglesia en la sociedad civil: así como la Iglesia es incompetente en el gobierno de los asuntos temporales, así el Estado lo es en materias religiosas; por consiguiente es justo que en cada uno de estos ámbitos, haya libertad para seguir las propias convicciones y la propia vocación personal, guiados por una conciencia cristiana bien formada, y dentro del respeto al legítimo orden público.

Lo dicho hasta ahora es consecuencia del derecho divino progresivamente mejor conocido y formulado con mayor o menor acierto técnico, en cuanto elemento esencial de la constitución de la Iglesia. Cualquier formulación y aplicación humana de los postulados del derecho divino, extraídos como datos de la Revelación, no pueden cerrar el dinamismo que le es inherente y que siempre puede obtener nuevas profundizaciones y aplicaciones, a través de la historia. De este modo, también en los "derechos de libertad", sancionados en la legislación canónica vigente, nos es dado encontrar una formulación jurídica, siempre perfectible, de aquella "dignidad y libertad de los hijos de Dios"(L.G.9 \& 2), que constituye la condición básica de quienes forman el pueblo de Dios; ciertamente que las mociones del Espíritu en la conciencia eclesial, a través de la investigación teológica, el ejercicio del Magisterio eclesiástico, los estilos de vida cristiana de la comunidad de los fieles (cf.L.G.12), han de impulsar hacia nuevas aplicaciones y consecuencias.

(27) "Los fieles laicos tienen derecho a que se les reconozca en los asuntos terrenos aquella libertad que compete a todos los ciudadanos; sin embargo, al usar de esa libertad, han de cuidar de que sus acciones estén inspiradas por el espíritu evangélico, y han de prestar atención a la doctrina propuesta por el magisterio de la Iglesia, evitando a la vez presentar como doctrina de la Iglesia su propio criterio, en materias opinables". (can.227) cf. Lumen gentium 36 \& 4 y 37 \& 3; Apostolicam actuositatem 24 \& 7, Presbyterorum Ordinis 9 \& 2, Gaudium et Spes 43 \& 2. Cong. para la Doctrina de la Fe, Nota doctrinal sobre algunas cuestiones relativas al compromiso y la conducta de los católicos en la vida política (24-nov.- 2002).

(28) "Compete siempre y en todo lugar a la Iglesia proclamar los principios morales, incluso los referentes al orden social, así como dar su juicio sobre cualesquiera asuntos humanos, en la medida en que lo exijan los derechos fundamentales de la persona humana o la salvación de las almas" (can.747 \& 2; cf.Christus Dominus 12; Dignitatis Humanae, 15; Gaudium et Spes 76, 89. 


\section{LIBERTAD Y AUTORIDAD EN LA EDIFICACIÓN DE LA COMUNIDAD ECLESIAL}

Los dos momentos de la autoridad y de la libertad, aun cuando se sitúan potencialmente contrapuestas y en relación de tensión dialéctica, hallan un punto de convergencia en la realidad mistérica de la communio que caracteriza a la Iglesia. Ambas, en su respectiva dimensión, tienen que salvaguardar, potenciar y desarrollar esta communio. Vimos que la autoridad en la Iglesia tiene una finalidad ministerial irrenunciable que la mueve a edificar la comunión, apartándola de replegarse en sí misma. Por otro lado, la valorización de los derechos del fiel y de los ámbitos de libertad que son suyos -asunto de especial importancia en el desarrollo del derecho canónico postconciliar- no puede echar al olvido que cada fiel, por razón de su condición bautismal, vive y actúa íntimamente inserto en una comunidad que no se organiza ni se estructura según esquemas institucionales puramente humanos, sino sobre la base de un mandato divino que tiene su origen en el amor redentor de Cristo. Se da, por consiguiente, una exigencia primaria en el modo de considerar los derechos de los fieles que el legislador ha expresado con claridad al señalar " $L o s$ fieles están obligados a observar siempre la comunión con la Iglesia, incluso en su modo de obrar" (can. 209) y que en el ejercicio de sus derechos han de tener constantemente presente el bien común de la Iglesia (cf. can. 223 \& 1). El fiel cristiano no se sitúa ante los pastores en un plano de conflicto, sino de comunión; por lo tanto, no puede ser concebido como una entidad individual, contrapuesta a la colectividad, sino como un sujeto "a quien toda la comunidad de los cristianos le está misteriosa, pero realmente inmanente". La fundamental unión/distinción entre el sacerdocio común y el sacerdocio ministerial (L.G.10), implica una recíproca inmanencia, dado que el sacerdocio común continúa subsistiendo en el sacerdocio ministerial y este existe y se justifica solo en función y servicio de aquel.

Tampoco en el plano estrictamente jurídico, la relación de cada fiel con los demás miembros de la comunidad -incluidos los que ejercen el ministerio de la autoridad- puede ser vista como una "relación de polaridad concurrente". Los derechos de los fieles, en efecto, no pueden oscurecer la necesaria referencia a la communio, que es la razón de su reconocimiento y que caracteriza su modo de ser.

Hay que evitar una consideración reductiva que viera a la communio simplemente como un mecanismo para mantener y reforzar el statu quo y no tuviera una mirada propulsora como edificación y progresivo desarrollo. Tampoco se trata de reducirla a un nivel puramente exhortativo o de un genérico compromiso moral. Tal instancia "comunional" debe traducirse en una específica dimensión jurídica que impulse desde dentro al derecho de la Iglesia y se convierta en una permanente inspiración de fondo; esta communio, más que cualquier otra dimensión, está en condiciones de dar al derecho de la Iglesia una fisonomía propia, que lo distinga de cualquier asimilación a los ordenamientos jurídicos seculares y lo haga efectivamente apto para regular la vida del pueblo de Dios.

Situándonos en un plano más cercano a la praxis, el derecho tiene que recibir el impulso para descubrir, e inventar, si es necesario, instrumentos, instituciones y modalidades de ejercicio que favorezcan la edificación de esta communio; este esfuerzo tendría que ser patrimonio de todos los fieles, en lo que toca a cada uno. En 
este sentido, hay que revisar y potenciar las instancias de participación de los fieles en la vida y en el gobierno de la Iglesia. Entre los derechos/deberes fundamentales de los fieles se halla, junto al de la obediencia cristiana a los Pastores, cuando, en cumplimiento de sus funciones enseñan como maestros de la fe o gobiernan como rectores de la Iglesia, se sitúa el derecho, y aun el deber de exponer su punto de vista a los Pastores acerca de lo que toca al bien de la Iglesia, de acuerdo al propio conocimiento y competencia; se prevé allí mismo, la existencia de una conveniente opinión pública al interior de la Iglesia (29) (cf. can. 212 \&\& 1-3). En cuanto a una más directa participación en órganos de gobierno, en el plano de cooperación al ejercicio de la potestad de jurisdicción y a lo que es propio de los clérigos, se han multiplicado las posibilidades de inserción en organismos colegiados de consulta, de ayuda y de preparación de las leyes y actos de la jerarquía. Mediante estas formas de participación se ponen en condiciones de dar un aporte, que no ha de ser de mera suplencia o integración a lo realizado por el clero, sino ayuda específica y original, que nace de su experiencia como laicos(as) inmersos en el mundo de las realidades temporales y de su vocación para actuar en ellas "a manera de fermento de transformación" (L.G.31). Aquí encuentra un real significado lo dispuesto en el canon 127 \& 3: "Todos aquellos cuyo consentimiento o consejo se requiere, están obligados a manifestar sinceramente su opinión..."

Se ha abierto una vía que ha de ser transitada y ampliada siempre más, de modo que el derecho de la Iglesia ayude a las comunidades de la Iglesia y a cada uno de los fieles, al deber-ser que nace de la voluntad de Cristo, enseñado y guiado visiblemente por Pedro y los Doce en la persona de sus legítimos sucesores e invisiblemente por la acción del Espíritu; para la realización de tal deber-ser es ineludible la respuesta adulta y responsable de cada uno desde su respectiva vocación / función eclesial.

En el derecho de la Iglesia hay que descubrir la "caridad de la justicia": es Dios mismo quien, asimilando el mandato del amor a El con el del amor al prójimo, no acapara el monopolio de los mandatos, sino que llama a desentrañar y reformular incesantemente los contenidos normativos del fundamental precepto de la caridad. Este es el gran desafío actual para el derecho de la Iglesia: realizar cada vez más su condición de "ordinatio communionis", de modo que llegue a ser un efectivo instrumento de edificación de la Iglesia.

\section{RESUMEN}

A través de la historia de la Iglesia desde la perspectiva específica de estas reflexiones, es dado ver las alternativas teórico-prácticas que ha asumido la autoridad jerárquica, sea que ésta se refiera al emperador cristiano (en los primeros siglos) o al sucesor de Pedro, considerado en sí mismo o en relación con el Colegio de los Obispos.

(29) Hace ya muchos años, Pío XII recordaba a los periodistas católicos, la necesidad de la opinión pública al interior de la Iglesia: cf. discurso del 17-febr.-1950 (A.A.S.,42 (1950), 251). Suya es también la consigna dada en el Primer Congreso Mundial del Apostolado de los Laicos: "En las batallas decisivas, a veces las iniciativas más lúcidas parten del frente mismo. La historia de la Iglesia ofrece numerosos ejemplos de ello"(14-oct.1951). 
La segunda parte ahonda en las consecuencias que es posible extraer del magisterio del Vat. II por lo que respecta al derecho Canónico.

Este requiere ser valorado y aplicado en estrecha conexión con el dato revelado y con la naturaleza mistérica de la Iglesia.

En este proceso de redescubrimiento y valorización de la dimensión jurídica eclesiástica, se perfilan dos elementos inter-relacionados que caracterizan toda experiencia comunitaria en la Iglesia: la instancia gubernativa y la autonomía personal.

La autoridad de la Iglesia deriva de los datos de la Revelación y se transmite fundamentalmente por vía sacramental en el Orden sagrado; dicha potestad es ministerial y asume un carácter colegiado.

La configuración de la autoridad en la Iglesia en términos de ministerialidad o servicio, lleva a confirmar la centralidad del fiel cristiano en todo el ordenamiento jurídico canónico.

Los dos elementos -autoridad y autonomía personal- aun cuando se sitúan potencialmente contrapuestos hallan un punto de convergencia en la Iglesia, entendida fundamentalmente como una comunión.

\begin{abstract}
Through out the history of the Church, the hierarchical authority has adopted some theoretical and practical approaches with regards to either the Christian emperor (in the early centuries) or the successor of Peter, considered by himself or in relation to the Episcopal college. Then the article looks into the consequences of the Vatican Council II teachings regarding the Canon Law, which needs to be considered and applied in close connection to the revealed truth, and the nature of the Church. In this process of rediscovering and appraising the Church's juridical dimension, two characteristic elements are intertwined: the ruling instance and the personal autonomy. The authority of the Church stems from the Revelation, and is passed on fundamentally by means of the sacred Order. This supremacy is ministerial and adopts a collegial character. The shaping of the ecclesiastical authority in terms of service confirms the centrality of the Christian faithful within the juridical canonical order. Even though both elements -authority and personal autonomy- may seem to conflict, they do converge in the Church, essentially understood as a communion.
\end{abstract}

